\title{
EFFECTS OF CHINESE CURRENCY REVALUATION ON WORLD FIBER MARKETS
}

\author{
SUWEN PAN, SAMARENDU MOHANTY, MARK WELCH, DON ETHRIDGE, and MOHAMADOU FADIGA*
}

\begin{abstract}
A partial equilibrium model is used to analyze effects of Chinese currency revaluation on world fiber markets. Unique characteristics of this model include incorporation of a regional supply response of cotton, substitutability between cotton and manmade fibers, and linkage between raw fiber and textile sectors. Simulation results show renminbi revaluation is likely to increase China's fiber imports and lower domestic cotton prices. Internationally, the world cotton price, polyester price, and cotton trade are expected to increase. A scenario modeling currency devaluation in China is run to test the stability of the model and ascertain its accordance with economic theory. (JEL F17, F42, F47, O2)
\end{abstract}

\begin{abstract}
With a view to establish and improve the socialist market economic system in China, enable the market to fully play its role in resource allocation as well as to put in place and further strengthen the managed floating exchange rate regime based on market supply and demand, the People's Bank of China, with authorization of the State Council, is hereby making the following announcements regarding reforming the RMB exchange rate regime:

Starting from July 21, 2005, China will reform the exchange rate regime by moving into a managed floating exchange rate regime based on market supply and demand with reference to a basket of currencies. RMB will no longer be pegged to the U.S. dollar and the RMB exchange rate regime will be improved with greater flexibility.
\end{abstract}

$$
\text { - The People's Bank of China }
$$

*The authors thank anonymous reviewers for their comments and suggestions. Material in this publication is based on work supported by the Cooperative State Research Education and Extension Service, U.S. Department of Agriculture.

Pan: Research Scientist, Department of Agricultural and Applied Economics, Texas Tech University, P.O. Box 42132, Lubbock, TX 79409. Phone 806-742-2821, Fax 806-742-1099, E-mail s.pan@ttu.edu

Mohanty: Associate Professor, Department of Agricultural and Applied Economics, Texas Tech University, P.O. Box 42132, Lubbock, TX 79409. Phone 806-7422821, Fax 806-742-1099, E-mail sam.mohanty@ttu.edu

Welch: Research Associate, Department of Agricultural and Applied Economics, Texas Tech University, P.O. Box 42132, Lubbock, TX 79409. Phone 806-7422821, Fax 806-742-1099, E-mail james.m.welch@ttu.edu

Ethridge: Professor, Department of Agricultural and Applied Economics, Texas Tech University, P.O. Box 42132, Lubbock, TX 79409. Phone 806-742-2821, Fax 806-742-1099, E-mail don.ethridge@ttu.edu

Fadiga: Research Scientist, Department of Agricultural and Applied Economics, Texas Tech University, P.O. Box 42132, Lubbock, TX 79409. Phone 806-7422821, Fax 806-742-1099, E-mail mohamadou.fadiga@ ttu.edu

Contemporary Economic Policy (ISSN 1074-3529)

Vol. 25, No. 2, April 2007, 185-205

Advance Access publication June 9, 2006

\section{INTRODUCTION}

This article examines the effects of Chinese renminbi (RMB) revaluation on the world fiber market. ${ }^{1}$ China is the largest cotton producer, consumer, and importer in the world. The U.S. Department of Agriculture (USDA) expects China to import more than 9 million bales in 2004/5, accounting for more than $30 \%$ of the world cotton trade. RMB revaluation is likely to make the price of imported cotton relatively cheaper in the Chinese market. On the other hand, China is also the world's leading exporter of textile products. At the end of 2004, China accounted for $20 \%$ of the global textile trade, with some analysts predicting that this could rise even higher after the trade restricting quotas of the Multi Fiber Agreement are lifted in 2005 (U.S.China Economic and Security Review Commission [USCC] 2005). If RMB appreciation

1. The term renminbi means "people's currency," whereas yuan is the basic unit of measure for the renminbi.

\section{ABBREVIATIONS}

AIC: Akaike Information Criteria

CPI: Consumer Price Index

FAPRI: Food and Agricultural Policy Research Institute

GDP: Gross Domestic Product

RMB: Renminbi

TRQ: Tariff Rate Quota

USCC: U.S.-China Economic and Security Review Commission

USDA: U.S. Department of Agriculture

WTO: World Trade Organization 
decreases China's textile exports and affects relative prices of imported fibers, this may significantly impact the world fiber market as well.

China's exchange rate policy has become a topic of considerable debate and subject to international disparagement in recent years. Although the RMB has been pegged to the U.S. dollar since 1994 at around 8.28 yuan, international criticism of the currency regime has occurred only recently. Critics have charged that by undervaluing its currency, China has gained an unfair price advantage in its exports to the United States and other countries. The United States, a strong proponent of the currency peg during the Asian financial crisis of 1997, has reversed its position in recent years because of concerns by U.S. companies and politicians of the growing trade deficit with China (Schumer and Graham 2005).

One complaint stems from increased job losses in the U.S. manufacturing sector and production outsourcing to other regions of the world, especially China. The contraction of the U.S. manufacturing sector coupled with a widening U.S.-China trade deficit has intensified this criticism, with groups such as the National Association of Manufacturers urging the U.S. government to persuade China to reform its currency regime. In recent testimony before the House Subcommittee on Domestic and International Monetary Policy, Trade, and Technology, Goldstein (2003) of the Institute for International Economics indicated that undervaluation of the RMB is on the order of $15 \%$ to $25 \%$. Others such as Preeg (2003) and Kujawa (2005) argue that RMB is undervalued by as much as $40 \%$, contributing to the widening trade deficit between the United States and China.

In response to growing international pressure, particularly from the United States and other large economies, China recently moved from a hard peg of 8.28 yuan per US\$ to a managed float, allowing the value of the RMB to vary within limits. The initial implementation of this revaluation policy resulted in an appreciation of the yuan to 8.08 per US\$, a $2.4 \%$ currency adjustment. Many economists expect the yuan to gain an additional $5 \%$ in value relative to the U.S. dollar in the near term (Hilsenrath and Kissel 2005; Isadore 2005).

The likelihood of further revaluations of the RMB, as well as the economic effects of China's more market-oriented monetary system, are unclear. Lau (2003) estimated that a $20 \%$ increase in the value of the RMB would increase the cost of Chinese goods by $4 \%$, but this increase in costs might not be passed on to consumers because companies that export from China may absorb the exchange rate shift and cut profits instead. In the case of agricultural trade, the impact may be different from those in the manufacturing sector due to unique characteristics of agricultural markets.

The effect of exchange rate misalignment and revaluation on agricultural exports and imports, both in terms of direction and magnitude, has been of especial interest to agricultural economists since the U.S. adoption of a flexible exchange rate system in 1973. The over- or undervaluation of the U.S. dollar relative to the currencies of other nations has been offered as an explanation for rising or declining economic circumstances of American agricultural producers. Schuh's (1974) seminal article posits that "the exchange rate has been an important omitted variable in past interpretations of U.S. agricultural development and trade problems" and goes on to provide a theoretical framework for examining the relationship between the exchange rate and the fortunes of U.S. agriculture. Since then, many studies have investigated the question of the effects of exchange rates on international trade for different countries and commodities with a variety of methods. Chambers and Just (1979) and Kristinek and Anderson (2002) provided extensive reviews of empirical studies of this relationship. Although many of these research efforts have confirmed Schuh's propositions (Bolling 2000; Chambers and Just 1981; Kim et al. 2004; Krueger et al. 1988; Orden 2002; Schuh 1984; Shane 2001; Tweeten 1992), others have failed to find correlations of statistical significance (Batten and Belongia 1984). Specifically, Vellianitis-Fidas (1976) examined the effects of U.S. dollar devaluation in 1971 and 1973 on the exports of U.S. agricultural products. The results suggested that imports of cotton seemed more likely than the other commodities to be affected by the exchange rate variations.

Variation of results may be explained by myriad factors, such as the choice of econometric model and its specification and flexibility, issues related to commodity aggregation, the nature of agricultural trade itself, specifically supply, demand, and trade policies that may cushion or distort exchange rate effects. As Kristinek and Anderson (2002) conclude, while there is little disagreement whether 
FIGURE 1

Effects of Chinese Currency Revaluation on the World Cotton Market

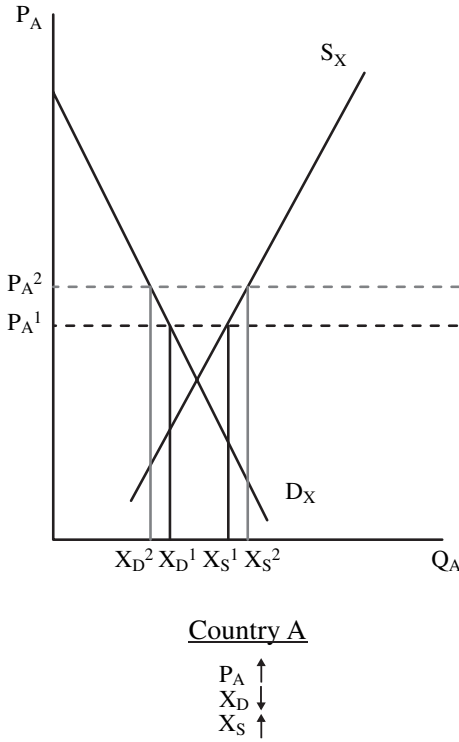

exchange rates play a role in affecting trade, questions remain as to how significant of a role they play and the conditions under which they are most influential.

The objective of this study is to estimate the effects of China's currency revaluation on the world fiber market. To accomplish this objective, an analysis is conducted using a partial equilibrium world fiber model. For analysis, four different scenarios are considered:

- $2 \%$ appreciation of the RMB to estimate the effects of recent monetary adjustments;

- 5\% appreciation, which many economists, both in China and the United States, expect in the near term (Bradsher 2005; Hilsenrath and Kissel 2005; Isadore 2005);

- $15 \%$ appreciation, which represents the lower range of estimates of how much the yuan is undervalued compared to the U.S. dollar (Goldstein 2003); and

- $5 \%$ depreciation of the RMB to test the authors' model for the effects of relative currency depreciation and empirically verify the theoretical framework presented.

The remainder of the article is organized as follows. In the following sections, a conceptual framework for analyzing this question is presented. This is followed by a description of the partial equilibrium model used to estimate the effects of RMB revaluation. Simulation results are then reported along with a discussion of policy implications.

\section{CONCEPTUAL FRAMEWORK}

Following is a theoretical discussion of expected changes in imports and exports as a result of currency realignment. The presentation here considers the present situation of China as a net importer of raw cotton whose currency in undervalued relative to a net cotton exporter, such as the United States. The conceptual analysis presented here provides the expected directional changes in components of the world cotton market due to the revaluation of an importing country's currency relative to the currency of an exporting trading partner. As shown in Figure 1, country A represents the exporting country, country B represents the importing country, and the middle graph represents the world market interchange of excess supply $(E S)$ and excess demand $(E D)$ schedules derived from countries A and B.

A distinguishing feature of the trade impact illustration of Figure 1 is the effect on world trade of a tariff rate quota (TRQ) imposed by the importing country. China, as part of their World Trade Organization (WTO) commitments, uses cotton import restrictions in the form of a TRQ to impose a higher tariff 
on imports above a specified quota level. ${ }^{2}$ With TRQs in place, excess demand is unaffected down to point $\mathrm{B}$, where the demand schedule intersects the TRQ level. This is referred to as the demand for in-quota imports. At the point of the TRQ, the demand function is kinked by the amount of out-of-quota tariff on any imports above this quantity.

In the presence of a TRQ, the quantity of world trade is given by the intersection of excess supply $(E S)$ and excess demand $\left(E D^{1}\right)$ : $Q_{T}^{1}$. The commodity price in country A, $P_{A}^{1}$, is found at this same intersection of $E D^{1}$ and $E S$ in the world market. At this price, the quantity demanded in country $\mathrm{A}$ is $X_{D}^{1}$, quantity supplied is $X_{S}^{1}$, and the quantity exported is $X_{S}^{1}$ minus $X_{D}^{1}$. The initial price in country $\mathrm{B}, P_{B}^{\mathrm{l}}$, is determined by the intersection of excess demand for country $\mathrm{B}$ (line $A A$ ) and the quantity of goods supplied to the world market as a consequence of excess supply and excess demand in the face of the TRQ $\left(Q_{T}^{1}\right)$. The divergence of prices between $P_{A}^{1}$ and $P_{B}^{1}$ is one clear indication of the tradedistorting effects of a TRQ. The quantity of goods supplied in country B is given by $M_{S}^{1}$, quantity demanded by $M_{D}^{1}$, and the amount imported $M_{D}^{1}$ minus $M_{S}^{1}$.

Now let the currency of country B appreciate relative to the currency of country A that will make imports from country A cheaper thus increasing demand for exports from country A to country B. Excess demand will shift right from $E D^{1}(A B C D)$ to $E D^{2}(E F G H)$.

The result of currency appreciation in country B relative to the currency of country $A$ is again given by the intersection of the new excess demand function $\left(E D^{2}\right)$ and the unaffected excess supply schedule $(E S)$. This results in an increase in the quantity of goods traded in the world market (a move from $Q_{T}^{1}$ to $Q_{T}^{2}$ ) causing the price level in country A to increase to $P_{A}^{2}$. In response to a higher price in the exporting country $A$, the quantity demanded decreases to $X_{D}^{2}$, the quantity supplied increases to $X_{S}^{2}$, and the quantity of goods available for export increases by

2. In-quota import levels have been set to rise from 740,000 metric tons in 2002 to 890,000 metric tons in 2004 with a tariff of $1 \%$. The out-of-quota tariff, which was $76 \%$ above 780,000 metric tons in 2002 , is scheduled to drop to $67 \%$ above 820,000 metric tons in $2003,58 \%$ above 860,000 metric tons in $2004,49 \%$ above 890,000 metric tons in 2005 , and $40 \%$ above 890,000 metric tons in 2006. China has not agreed to nor is bound to further increase quota levels or decrease tariff levels beyond 2006.
$\left(X_{S}^{2}-X_{D}^{2}\right)$ minus $\left(X_{S}^{1}-X_{D}^{1}\right)$. In importing country $\mathrm{B}$, the price response is again measured by the intersection of the world quantity traded $\left(Q_{T}^{2}\right)$ after the currency adjustment and the unaffected excess demand curve still relevant for country $\mathrm{B}$, line $A A$. The increase in quantity traded results in a lower domestic price in country $\mathrm{B}\left(P_{B}^{2}\right)$, decreased quantity supplied by country B's producers $\left(M_{S}^{2}\right)$, and in increase in quantity demanded $\left(M_{D}^{2}\right)$. The resultant increase in imports as a result of currency revaluation is given by $\left(M_{D}^{2}-M_{S}^{2}\right)$ minus $\left(M_{D}^{1}-M_{S}^{1}\right)$. Thus, as shown in Figure 1, the effect of currency revaluation in country $\mathrm{B}$ relative to country $\mathrm{A}$ is to increase the quantity traded, increase the price in country A, decrease the quantity demanded in A, increase the quantity supplied in $A$, decrease the price in $\mathrm{B}$, decrease the quantity supplied in $\mathrm{B}$, and increase the quantity demanded in B.

In the context of this study, the effect illustrated in Figure 1 is on the import of a raw material, cotton, as a component of a manufacturing process. As shown in this case of currency revaluation, imports from country A become relatively cheaper in country B, and the quantity traded increases. However, demand for cotton in China is derived demand from its textile industry. If currency revaluation causes the textile exports from China to its trading partners to become more expensive, it is expected that the domestic demand function for cotton in China would decrease (shift to the left). Such a movement would shift the excess demand function in the world market to the left as well. Conceptually, this would cause a decrease in cotton exports to country $\mathrm{B}$, decrease the price in country $\mathrm{A}$, and increase the price in country $\mathrm{B}$, with the contingent changes in domestic supply and demand in both A and B.

Therefore, currency revaluation by China is shown to produce contrary indications for the cotton trade. The net effect of such a change in monetary policy is likely to depend on many factors, among them the various supply and demand elasticities in these markets and the level of trade between countries affected by the currency realignment for both imported raw materials and exported finished goods. In the context of trade in the world cotton market between the United States and China, the conceptual framework presented here cannot predict which market (imported raw materials or exported manufactured goods) will 
FIGURE 2

Schematic Representation of the Chinese Fiber Model

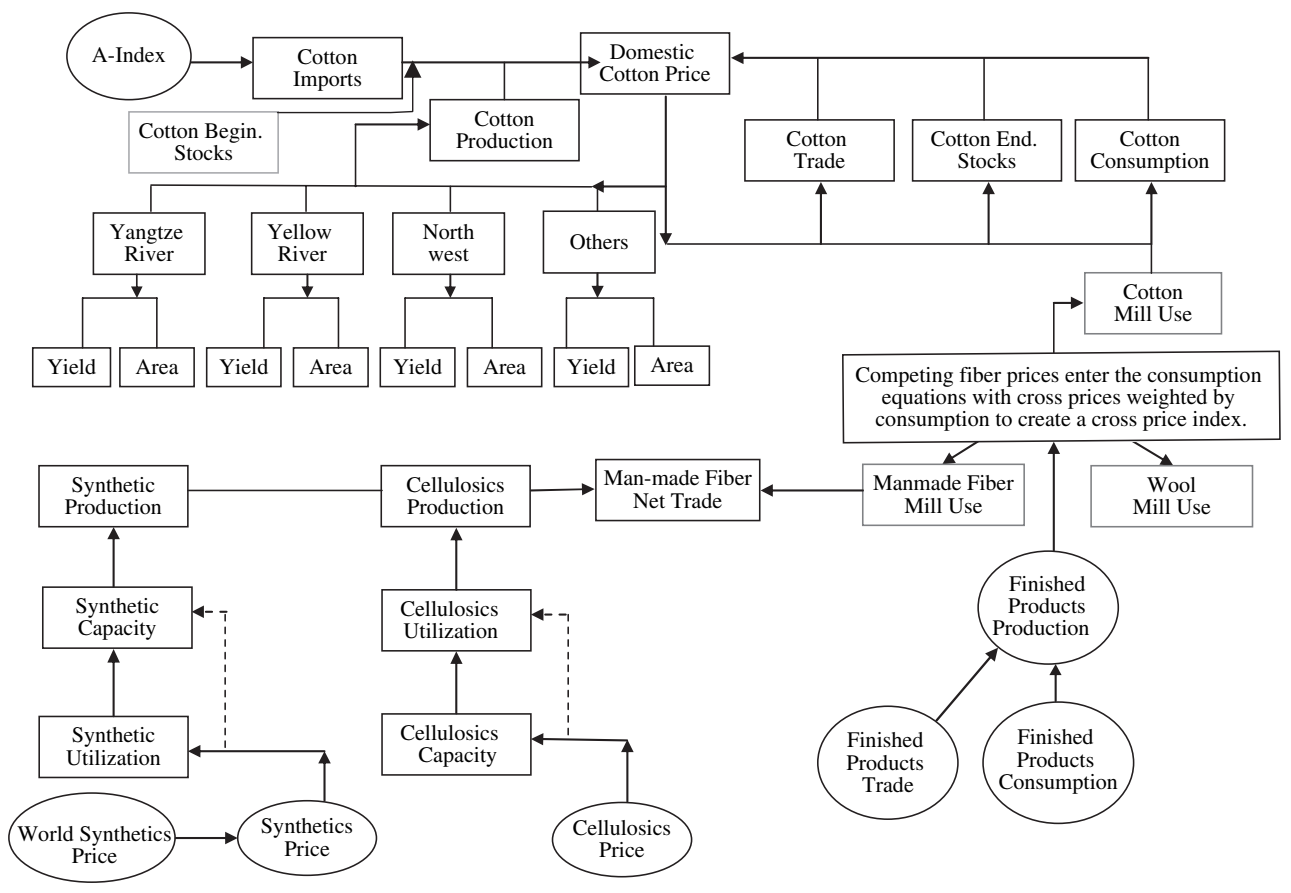

dominate. Additionally, in the presence of a TRQ, the revaluation of the RMB may have minimal to no effect on cotton imports depending on the equilibrium position of the excess demand curve. If China is operating somewhere on the vertical segment of the demand function where imports are constrained by the out-of-quota tariff, it is possible for imports to remain in the vertical range even after currency appreciation resulting in no change in the world market. Hence, this study develops an econometric model of the Chinese fiber market that is then linked to an existing world fiber model developed by Pan et al. (2004) to estimate the magnitude of the effect of $\mathrm{RMB}$ revaluation on the world fiber market.

\section{METHODS AND PROCEDURES}

Central to an estimation of the effects of RMB revaluation on the world cotton fiber market is the development of a structural econometric model of the Chinese fiber sector. This model incorporates the regional Chinese supply response of cotton, substitutability between cotton and manmade fibers, and linkage between the raw fiber and textile sectors. As shown in Figure 2, the Chinese model includes supply, demand, and market equilibrium for cotton and manmade fibers.

The domestic supply of cotton is shown as the sum of production, imports, and beginning stocks. Production is further decomposed into areas and yields, whereas manmade-fiber is modeled using capacity and utilization. Cotton demand is estimated following a two-step process in which total textile fiber consumption is estimated first, followed by allocations among the various fibers (cotton, wool, and manmade).

\section{A. Fiber Supply Model}

Cotton-producing areas in China are divided into four regions to account for heterogeneity in growing conditions arising from climatic differences, availability of water, and other natural resources that influence the crop mix in each of the regions. The four regions are: (1) the Yellow River or North China Plain, including the provinces of Henan and Shandong; (2) the Yangtze River region, including Jiangsu and Anhui Provinces; (3) the Northwest, primarily accounted for by the province of Xinjiang; and (4) the rest of China 
region, which accounts for all other cotton grown in China not included in the other three regions. Competing crops are different in the four regions, notably rice in the Yangtze River, soybeans and corn in the Yellow River, and corn in the Northwest.

Regional production is determined by estimating separate acreage and yield equations. Acreage planted is specified as a function of lagged area, expected prices of cotton and competing crops (which is represented by a oneperiod lag of the prices $\left.p_{i, t-1}^{c}, p_{i, t-1}^{s}\right)$, and policy variables:

$$
a_{i, t}^{c}=f\left(a_{i, t-1}^{c}, p_{i, t-1}^{c}, p_{i, t-1}^{s}, g_{i t}\right),
$$

where $a_{i}^{c}$ is the cotton acreage in the $i$ th region, $p_{i}^{c}$ and $p_{i}^{2}$ are $i$ th region cotton and competing crop prices, respectively and $\mathrm{g}$ represents dummy variables to account for policy shifts.

Regional cotton yield, $y_{i}$, is generally specified as a function of time to account for technological development in agricultural production. The total quantity of cotton produced, $C T P$, is the sum of each area's product of area harvested and yield per hectare:

$$
C T P_{t}=\sum_{i=1}^{4}\left(a_{i, t}^{c} * y_{i, t}\right) \text {. }
$$

Similarly, manmade fiber (synthetics and cellulosics) production is calculated by estimating capacity and utilization rates. Although new capacity is generally determined by expected market prices of both inputs and outputs several periods before planning and construction actually takes place, utilization depends primarily on current prices of inputs and outputs. Thus, production capacity of manmade fibers is specified as lagged prices of the domestic polyester price (output), the oil price (input), and a time trend. The lag length is determined by using the minimum Akaike information criterion (AIC) method. The capacity equation is specified as follows:

$$
\begin{aligned}
\text { MMFPC }_{t} & =f\left(P_{t-i}, O P_{t-i}, M M P F C_{t-1}\right) \\
i & =3,4, \ldots, 7
\end{aligned}
$$

where $M M F P C$ is the manmade fiber production capacity, $P P$ is the polyester price, and $O P$ is the crude oil price.

In contrast to the lagged values used is the estimation of manmade fiber production capacity, the utilization equation depends on current input and output prices (the ratio of current prices, $\left.P P_{t} / O P_{t}\right)$ and is specified as follows:

$$
\text { (4) } M M F C U_{t}=f\left(P P_{t} / O P_{t}, M M F C U_{t-1}\right) \text {, }
$$

where $M M F C U$ is the capacity utilization of manmade fibers.

Finally, for any given time period, the total production of manmade fiber is calculated as the product of manmade fiber capacity and utilization:

$$
M M F P R_{t}=M M F P C_{t} \times M M F C U_{t},
$$

where $M M F P R$ is the total manmade fiber production.

\section{B. Fiber Demand Model}

A two-step procedure is used for estimating fiber demand that connects textile output to fiber inputs. The first step involves the estimation of total domestic textile production, from which is derived the demand for all fibers. In the second step, total domestic textile production (total fiber demand) is allocated among the various fibers. Thus, demand for each fiber type (cotton, manmade, and wool) can be estimated according to its utilization in the textile production process.

Step 1. Total domestic textile production for a specific country is given by the following formula:

\section{Total Domestic Textile Production = Domestic Textile Consumption + Net Textile Trade.}

The model calculates per capita domestic textile consumption in fiber equivalents as a function of per capita income and textile and food price indices. Textile net trade is estimated as a function of Chinese and the U.S. apparel price indices.

Step 2. In the second step, total domestic textile production is allocated among the various fibers (cotton, wool, and manmade) using factor share equations derived from a translog cost function:

(6) $S_{i}=P_{i} D_{i} / C=\alpha_{i}+\sum_{j=1}^{3} \gamma_{i j} \ln P_{j}+\rho_{i} \ln Q_{i}$,

where $S_{i}$ is the $i$ th fiber share ( $i=$ cotton, manmade, and wool); $P_{i}$ is the price of the $i$ th fiber; 
$D_{i}$ is the quantities of $i$ th fiber; and $Q_{i}$ is the quantity of $i$ th fiber textile.

The demand system is estimated using nonlinear seemingly unrelated regression with symmetry $\left(\gamma i j=\gamma_{j i}\right)$ and homogeneity $\left(\sum_{j} \gamma_{i j}=1 ; \sum_{i} \rho_{i}=1\right)$ imposed. Theoretically, these assumptions ensure that the model conforms to the "reasonable restrictions" (Miller 2003) of utility maximization in demand theory (symmetry guarantees stability in consumer choice, and the homogeneity assumption means that demand preferences respond only to real, not nominal, changes in opportunities). Functionally, these assumptions assist the demand modeling process by decreasing the number of parameters to be estimated and increasing the degrees of freedom. Both advantages are important in this study due to the limited number of observations in the data set. The manmade fiber equation is omitted from the estimated system and is recovered through the adding-up constraint $\left(\sum_{i} \alpha_{i j}=1 ; \sum_{i} \gamma_{i j}=1\right)$ assuming weak separability, that is, the production of the textile sector in China operates independently of other manufacturing sectors of the Chinese economy.

Although some literature suggests using "demand models which are members of the differential family" such as the Rotterdam model, Working's model, or Selvanathan's model (Clements and Lan 2001), these approaches are less efficient due to data limitations and the number of parameters required to be estimated in these models ( $\mathrm{Li} 2003)$. The literature does suggest several advantages of using a translog function: (1) It is sufficiently flexible such that it can be used to approximate any twice-differentiable function without placing a priori restrictions on the production technology, (2) it is consistent with production theories, and (3) it imposes fewer restrictions than other functional forms (Chambers 1988; Segal 2002).

\section{DATA AND PARAMETER ESTIMATES}

Annual data for the period of 1979 to 2002 used in the estimation process were obtained from several different sources. Macroeconomic data such as gross domestic product (GDP), population, and Consumer Price Index (CPI) were obtained from various issues of the International Financial Statistics published by the International Monetary Fund (various issues). Price indices such as the tex- tile price index and food price index were collected from issues of the Chinese Statistical Yearbook. Cotton data concerning acreage, yield, production, mill utilization, ending stocks, and trade were collected from the Foreign Agricultural Service of the U.S. Department of Agriculture. Cotton farm and mill prices were obtained from the All China Federation of Supply and Marketing Cooperatives. The data on consumption and trade of textile and man-made fibers were obtained from the China Industrial Economic Statistical Yearbook, Chinese Rural Statistical Yearbook and Almanac of China's Textile Industry: 1979-99 (2001). Manmade fiber production capacity and utilization were collected from Fiber Organon (Fiber Economic Board various issues). Data on world cotton and polyester prices were obtained from the Cotton and Wool Situation and Outlook Yearbook published by the Economic Research Service, U.S. Department of Agriculture (2005). In this study, polyester price was used as the representative price for manmade fibers because the cellulosic sector accounts for such a small portion of the Chinese manmade fiber industry. Wool price refers to the UK domestic wool 50s CIF (cost, insurance, freight) equivalent and was collected from the International Monetary Fund. All prices and income were expressed in real terms before estimating the behavioral equations.

Parameter estimates of the behavioral equations of the China model, along with the regression statistics are reported in appendix A. Because parameter estimates are based on annual data from 1979 through 2002, the ramifications of small sample size in the estimation procedure become a concern. With only 24 observations, results may not be as stable, and variance estimation may inflate. However, reliable economic data from China has been difficult to obtain. Such information became more readily available in the late 1970 s as China began to reform its economy with more of a market orientation.

Appendix Table A.1 describes the acronyms of the variables included in the Chinese domestic model. The equations, parameter estimates (with standard errors in parentheses), and diagnostic statistics of the Chinese model are reported in Appendix Table A.2. In addition to the Durbin-Watson statistics reported, tests were conducted to detect higher order correlation. No significant effects were found. 
In the acreage equations (Table A.2, equations 1.1-1.4), the coefficient on the price ratio of cotton and competing crops is found to be statistically significant at the 10\% level for the Northwest and Yangtze River regions. This suggests at least partial support for the assertion that cotton acreage is responsive to both cotton and competing crop prices. In addition, the coefficient of the dummy variable for the period 1986-93 (representing a fertilizer and fuel subsidy program) is positive and significant for the Northwest and Yangtze. In the yield equations (equations 1.5-1.8), the coefficient on cotton price is found to be significant only for the Northwest region, although all of the price parameters have the expected positive signs. Similarly, parameter estimates for the manmade fiber production equations (equations 1.9-1.12) suggest that current production capacity of synthetic fibers is positively correlated to past petroleum prices. The indirect effect of past manmade fiber prices on manmade fiber capacity is of the correct sign but not of statistical significance. As expected, the synthetics utilization rate is positively and significantly correlated to the polyester/oil price ratio and the previous time period's capacity utilization rate.

As shown in the fiber demand section of Appendix Table A.2, the coefficients on the per capita income and textile price index are found to be statistically significant in the per capita Chinese textile consumption equation (equation 1.13). The estimated coefficient on relative prices of apparel in the United States and China is shown to be significant and of the correct sign in influencing the level of Chinese textile exports (equation 1.14). As the price ratio of Chinese apparel to U.S. apparel increases, the net textile trade will decline, whereas a decrease in this ratio (U.S. apparel prices increase relative to China's apparel price index) will result in an increase in net textile trade. The time trend is included to represent the effects of trade liberalization in the world textile market, and the estimated coefficient is found to be both positive and significant at the $1 \%$ level. In the second step of fiber demand estimation, textile production is allocated among competing fibers (cotton and manmade) based on relative prices using the translog cost function (equations 1.15 and 1.16). The parameter estimates reach at least the minimal $10 \%$ statistical significance level for each variable: textile fiber, cotton price, wool price, and manmade fiber price. These estimates are then used to calculate ownand cross-price elasticities for each fiber and will be discussed shortly.

The last section of Appendix Table A.2 reports the parameter estimates for the ending stock and cotton trade equations (equations 1.17-1.19). The coefficients on cotton supply and the cotton price are significant in the cotton ending stock equation. Similarly, the estimated coefficients on the world to domestic cotton price ratio and income are significant in the cotton import equation, and the world to domestic cotton price ratio and cotton mill use to production ratio are significant in the cotton export equation. All parameters have the expected signs. For example, the coefficient of the domestic cotton price is significant and negative in the ending stock equation confirming expectations that carryover stocks decline as cotton prices increase. Chinese cotton imports are estimated to decline as the ratio of the world cotton price to China's domestic price increases and vice versa.

In Appendix Table A.3 and Appendix Table A.4, the parameters of Table A.2 are converted to elasticities at their sample means and are reported according to Chinese fiber supply elasticities and demand elasticities. Cotton price appears to have the greatest effect on acreage in the Northwest region. This may be explained by the rapid expansion of cotton acreage that has been taking place in this area for the last decade due to increased land availability. On the demand side (Table A.4), textile consumption is relatively income elastic with an estimated elasticity of 1.15 . At the mill level, all fiber demand own-price elasticities are negative and relatively inelastic, with wool being the most inelastic at -0.07 and cotton and manmade fiber being approximately the same, -0.33 and -0.32 , respectively. The positive compensated cross- price elasticities between cotton and manmade fibers confirm their substitutability at the mill level. The cross-price elasticities between manmade fibers and wool and cotton and wool are of different signs, but are both very close to 0 , suggesting virtually no substitution effect between wool and the other fibers.

Both the income and price elasticities reported here are a little higher than the results of Coleman and Thigpen (1991), Meyer (2002), and Clements and Lan (2001). This may be due to the different time period used 
for estimation. Coleman and Thigpen (1991) found the income elasticity of per capita fiber consumption to be 0.91 and the own- and cross-price elasticities of cotton to be around -0.06 and 0.06. Meyer (2002) estimated the income elasticity of cotton mill use to be 0.49 and the own-price elasticity for cotton to be -0.46 . The Rotterdam model of Clements and Lan (2001) showed the income elasticity of cotton to be 0.607 and the own-price elasticity of cotton to be -0.27 .

After estimating all equations, the model was solved simultaneously in a simulation program using SAS. Historical simulation of the model's equations was used to validate the estimated model using the components of the mean squared error (MSE) and the Theil inequality coefficients. Appendix Table A.5 presents the decomposition of the MSE and Theil $U$ statistics. Most of the bias and regression components' values are close to 0 , indicating that the simulated values do not tend to be higher or lower than their actual values. The disturbance components for most variables are close to 1, indicating that most of the errors in the simulated values are associated with randomness in the actual data series. Most of the Theil's inequality coefficients are close to 0 , which suggests that the model performs well.

\section{POLICY SIMULATIONS}

The authors follow the familiar 10-year forecasting time horizon of other agricultural outlook projections: Food and Agricultural Policy Research Institute's (FAPRI) World Agricultural Outlook (2005), USDA's "Agricultural Baseline Projections" (2005), and the Organisation for Economic Co-operation and Development and Food and Agriculture Organization of the United Nations (OECDFAO) "Agricultural Outlook" (2005). By estimating effects out to 10 years, it is possible to compare short-term effects to those of the medium term. It is often insightful to compare various aspects of the projection for effects that may be dramatic in the short term but soon mitigate in the presence of market forces. Other effects may be consistent over the time frame, and others may increase in magnitude. Each may have important implications for policy analysis.

To develop a 10-year baseline projection of supply, demand, and prices for cotton, manmade fibers, and textiles under a set of exog- enous assumptions, it is necessary to connect the estimated Chinese model to the world fiber model (a brief description of the world fiber model structure is provided in appendix B). The Chinese fiber model and the world fiber model are linked such that Chinese net import data for both cotton and manmade fiber may be used to endogenously solve for the world price of cotton and polyester in the world model. These world prices are then transmitted back to the Chinese model so that adjustments can be made in China's domestic cotton and manmade fiber sectors in response to changes in world prices.

The baseline projection assumes the continuation of current trade policies such as China's TRQ based on WTO commitments. The model is driven by a set of macroeconomic variables such as real GDP, the CPI, exchange rates, and population. Projections for these variables were obtained from the World and U.S. Agricultural Outlook (FAPRI 2005). Projections of other variables, such as acreage, yield, and prices for competing crops (e.g., wheat, rice, and corn), and crude oil prices were collected from the same source.

Once the baseline is developed, alternative scenarios are run for four different levels of exchange rates. These include one-time appreciations of $2 \%, 5 \%$, and $15 \%$ from the $2005 / 6$ level. In addition, another scenario is run with one-time depreciation of $5 \%$ to test the stability of the model and ascertain whether it is accordant with economic theory.

Tables C.1 and C.2 (in appendix C) and Figures 3 through 8 summarize the estimated effects of RMB revaluation on fiber markets in both China and the world. Market responses are calculated for a 10 -year period beginning in $2005 / 6$ and ending in 2014/15. Figure 3 presents the effects of $\mathrm{RMB}$ revaluation on China's textile exports and cotton imports; Figure 4 shows the expected effects on Chinese manmade fiber imports; Figure 5 illustrates the effects on the world cotton price (A-index); Figures 6 and 7 present the effects on major cotton exporters and importers in term of percentage changes in net trade; and Figure 8 depicts how a currency appreciation of 5\% contrasts with a currency depreciation of $5 \%$. This is shown in relative effects on the world cotton price and the quantity of world cotton traded.

RMB appreciation makes Chinese textiles more expensive in the world market, causing Chinese textile exports to decline. A $2 \%$ 
FIGURE 3

Effects of Chinese RMB Appreciation on Chinese Cotton Imports and Textile Exports

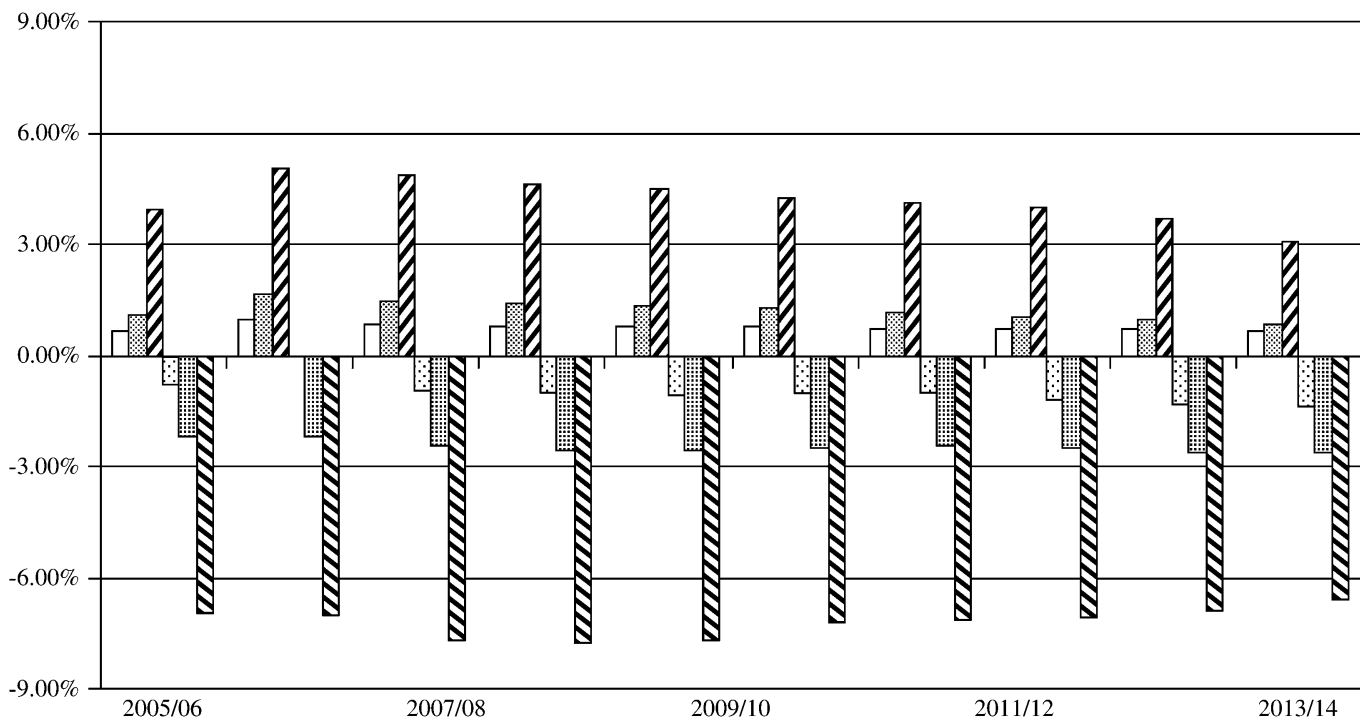

$\square$ Cotton Imports: $2 \% \quad$ 圈 Cotton Imports: $5 \% \quad \square$ Cotton Imports: $15 \%$

Textile Exports: $2 \%$ 眯 Textile Exports: $5 \% \quad \mathbf{N}$ Textile Exports: $15 \%$

FIGURE 4

Effects of RMB Appreciation on Chinese Manmade Fiber Imports

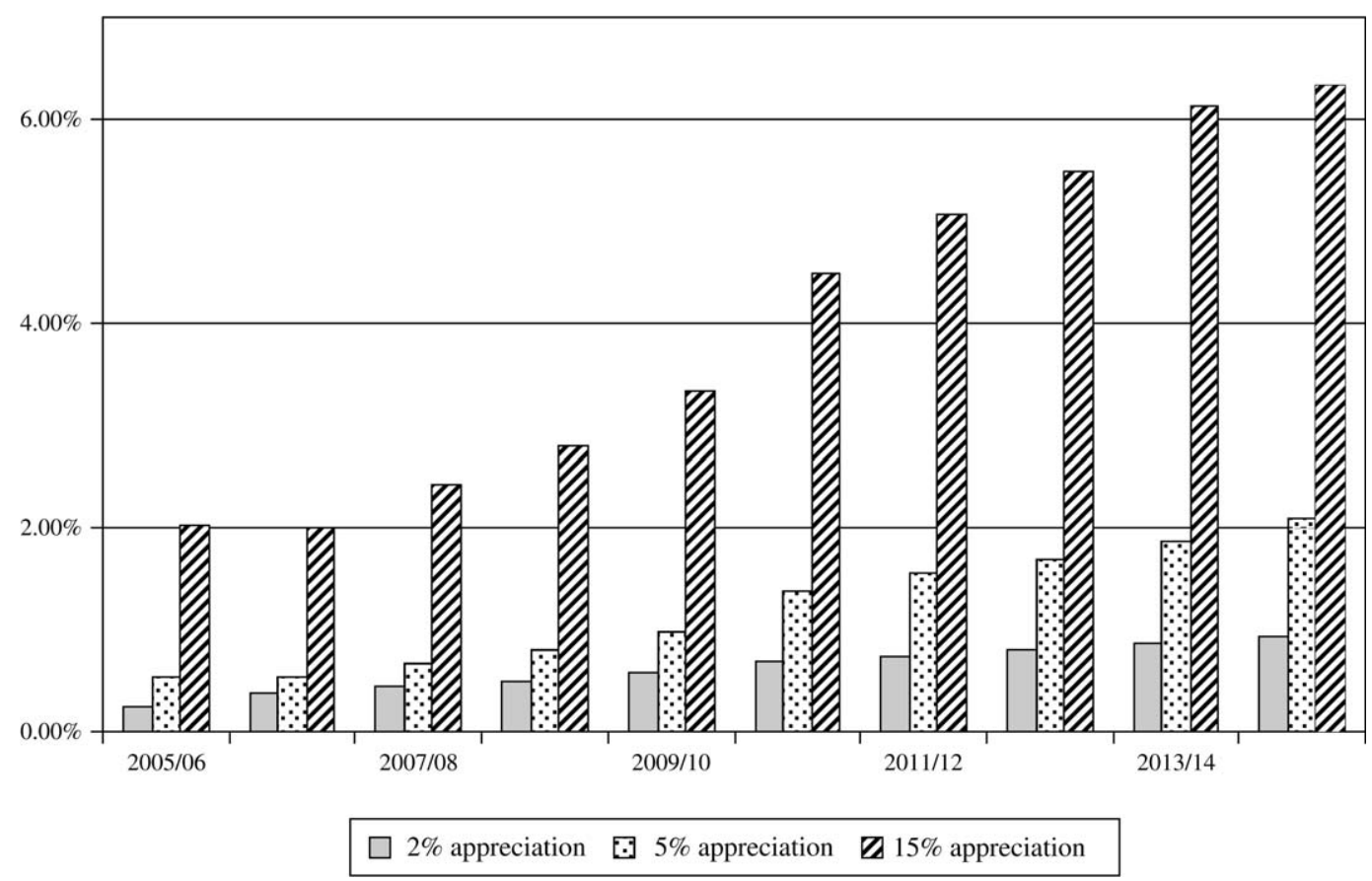


FIGURE 5

Effects of RMB Appreciation on the World Cotton Price

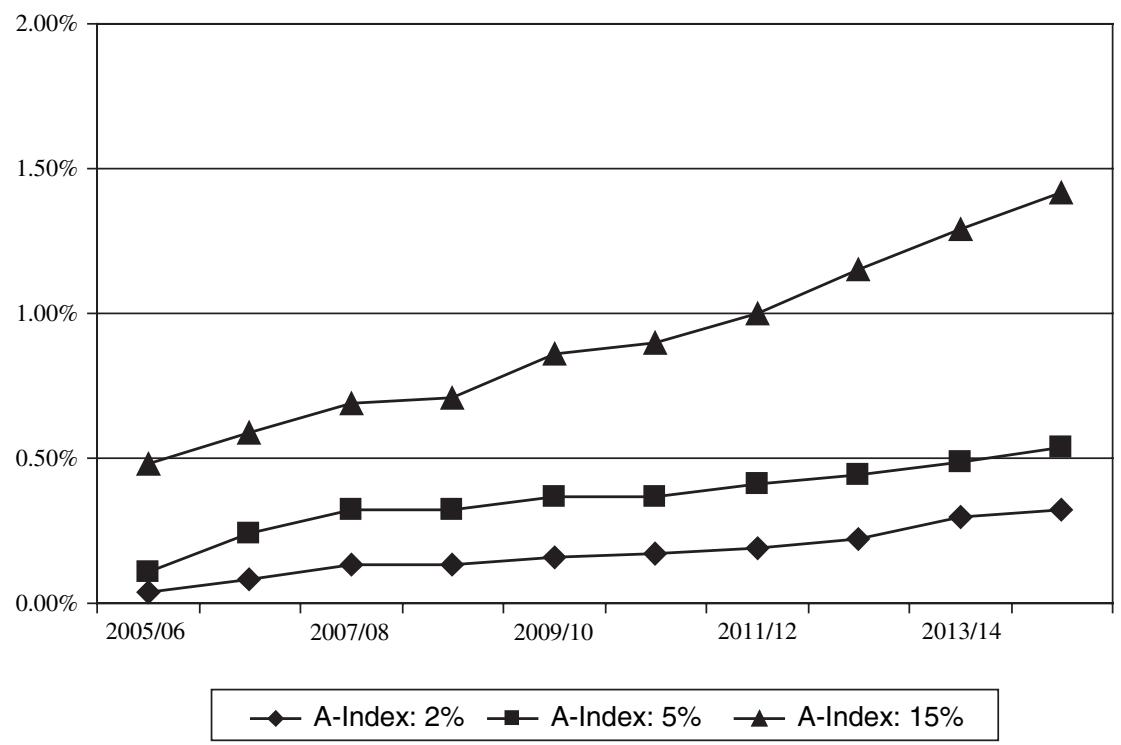

appreciation causes Chinese textile exports to decline by an average of $1.06 \%$ and a $5 \%$ appreciation results in an average annual decline of $2.47 \%$ (Figure 3 ). Even with the decline in textile exports, a 2\% currency appreciation causes the imports of both raw cotton $(+0.77 \%)$ and manmade fiber $(+0.61 \%)$ to increase. Similarly, a 5\% currency appreciation causes the domestic market price for cotton to decline: $-2.71 \%$ initially and by an average $-1.32 \%$ with a $2 \%$ revaluation. A $15 \%$ adjustment in the RMB lowers the price by approximately $10.25 \%$ in the first year and by an average of $-6 \%$. As shown in Table C.1, RMB revaluation causes China's domestic cotton price to remain below the baseline level. However, the magnitude of the impact on the domestic price steadily declines over time as

\section{FIGURE 6}

Average Effects of RMB Appreciation on Major Cotton Exporters

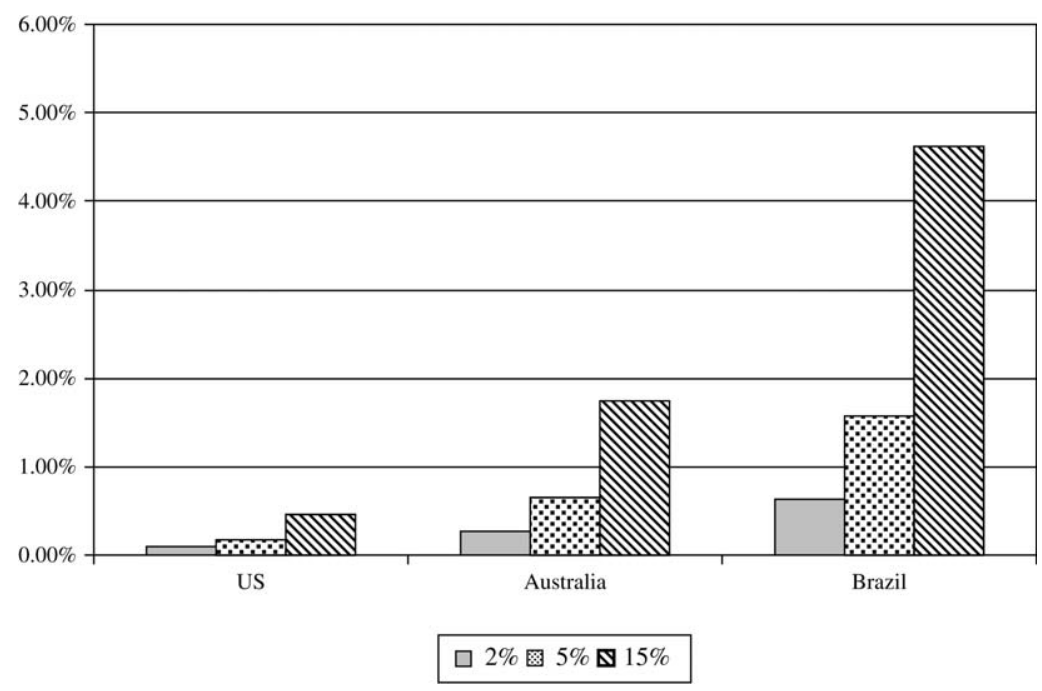


FIGURE 7

Average Effects of RMB Appreciation on Major Cotton Importers

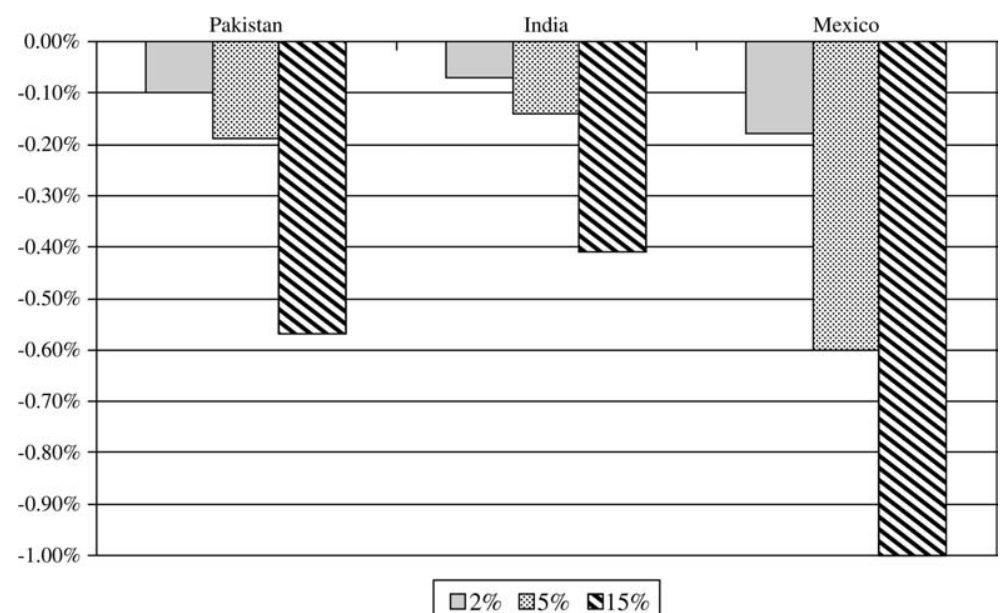

producers and consumers adjust to altered prices in both world and domestic markets.

China's domestic cotton production is projected to decline by 0.63 to $5.77 \%$ percent in the initial year of revaluation, depending on the level of adjustment. Again, regardless of the level of RMB appreciation, production effects steadily mitigate over time. Cotton mill use is virtually unaffected by RMB apprecia- tion at the $2 \%$ or $5 \%$ levels (all values are between $0 \%$ and $-0.23 \%$ ). Even at $15 \%$, the negative effects never exceed $-1 \%$.

Table C.2 summarizes the expected effects of RMB appreciation on the world cotton price, polyester price, and world cotton trade as well as the world's major cotton exporters and importers. The impact of appreciation on the total cotton trade is relatively small

FIGURE 8

Effects of 5\% RMB Appreciation and 5\% RMB Depreciation on World Cotton Price and Trade

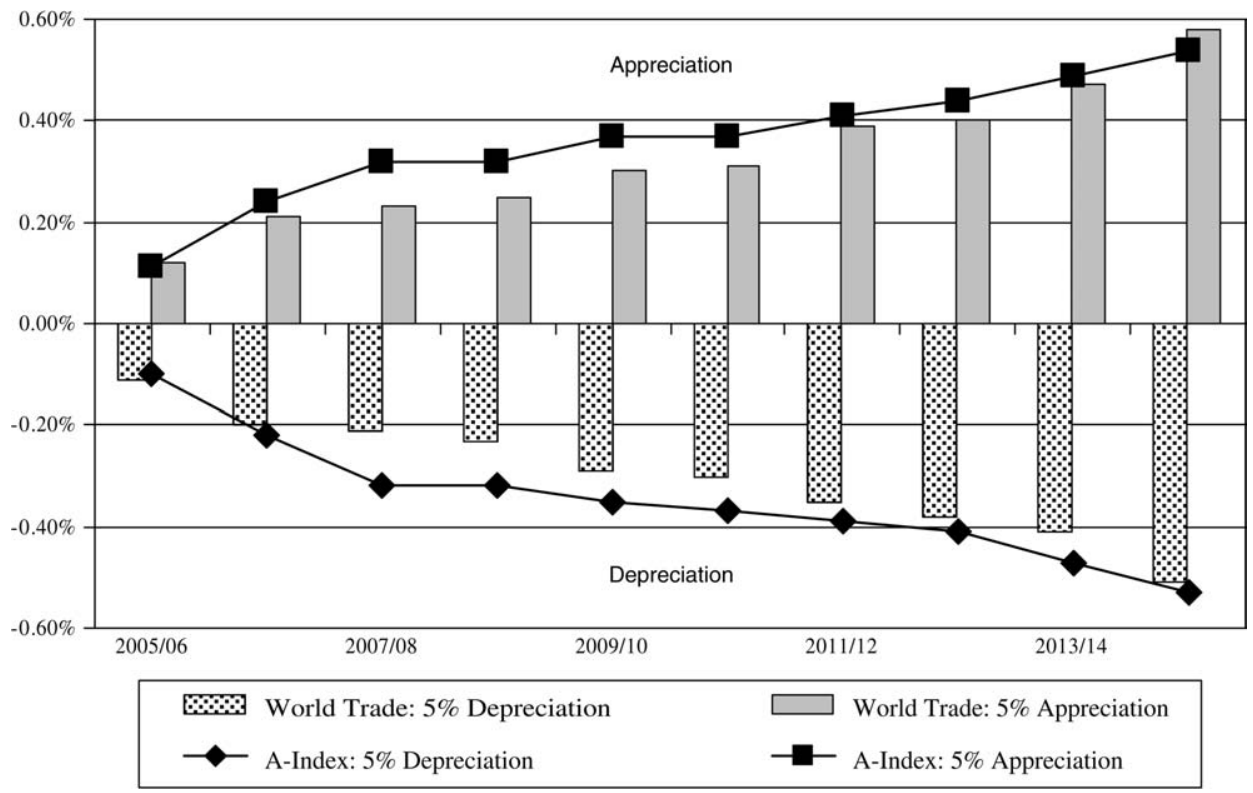


because the increase in Chinese imports is partly offset by a decline in imports by the rest of the world. Overall, the world cotton trade is affected positively, but only slightly. Even a 15\% RMB appreciation increases the world cotton trade by only 31,000 metric tons $(0.36 \%)$ in the first year. However, in contrast to many other variables, the magnitude of effects does increase throughout the scenario. The cotton A-index is projected to rise by an average of 0.17 to $1.19 \%$ depending on the level of appreciation (Figure 5). Again, perhaps in response to increases in the quantity of world trade, effects of RMB appreciation strengthen over time for world cotton prices.

Among major exporters, the United States, Brazil, and Australia seem most likely to capture additional market share. In percentage terms, Brazil is projected to expand its exports more than the United States or Australia. The United States, however, does show the greatest gains in absolute terms (Figure 6). From the import side, the higher world cotton price decreases imports by the rest of the world. Among major importers, regardless of the level of RMB appreciation, Japan fares the worst and India is the least affected.

The effects of a 5\% Chinese currency appreciation and $5 \%$ depreciation on the world cotton trade and price are presented in Figure 8. Consistent with economic theory and a testament to the validity of the model, these effects are approximate mirror opposites. A 5\% depreciation of the RMB results in an average world price decrease of $0.35 \%$ compared with the baseline. World trade is decreased by $0.30 \%$ under the same assumption. As before, the effects of currency adjustment (depreciation as well as appreciation) on prices and trade increase in magnitude over the life of the analysis.

Overall, appreciation of the RMB would impact the Chinese fiber markets with higher cotton imports and lower cotton prices and decreased textile exports. In addition, domestic cotton production is expected to decline due to lower prices. At the international level, cotton A-index and polyester prices are projected to rise due to higher import demand for cotton from China. World trade is projected to rise, with the United States, Brazil, and Australia being the major beneficiaries in terms of higher exports. But the extent of an increase in world trade is limited because of lower demand in major importing countries such as South Korea, Taiwan, Japan, India, and Pakistan. As confirmed by the model, opposite effects would be seen if China were to weaken the RMB rather than strengthen it.

\section{SUMMARY AND CONCLUSIONS}

This article analyzes the effects of an appreciation of China's currency on the world fiber markets using a partial equilibrium model. The Chinese component of the world fiber model is developed in this study and is connected to an existing world fiber model to conduct baseline projections and policy scenarios. The Chinese model includes a regional supply response of cotton, substitutability between cotton and manmade fibers, and linkage between raw fiber and textile sectors. The parameter estimates of the supply side equations suggest that cotton acreage is affected by both cotton and competing crop prices. On the demand side, fiber demand is estimated in two steps. First, textile production is derived by estimating textile consumption and trade. Second, it is allocated among various fibers based on relative prices. Textile consumption is determined by income and its own price.

Simulation results suggest that RMB appreciation would increase Chinese cotton imports and lower textile exports. However, most of the decline in textile exports is offset by expansion in domestic textile consumption and results in a slight decline in cotton mill utilization. The effects on the total world trade and the world price are limited due to the price effects on other main trading countries in the world. From the perspective of exporters, Brazil, Australia, and the United States appear well positioned to take advantage of any market expansion.

These results may have some policy implications. The findings that under a monetary policy of $\mathrm{RMB}$ revaluation China is likely to import more cotton and export fewer textiles, suggest that the effects tend to be stronger for Chinese domestic industries (both agriculture and textile) than for industries in foreign countries. Although cotton exporters appear to achieve some market gains, all other textile importers show trade losses. As noted earlier, a note of caution may be appropriate in regard to this study. The estimations presented here are based on a relatively small historical data set. Inflated standard errors diminish statistical explanatory power. The findings will be enhanced as more trade data, especially from 
China, becomes accessible. This study does however reveal some interesting correlations between monetary policy in an emerging world economic power and the levels of prices and quantities of goods traded in the rest of the world. More work is needed to provide convincing evidence of the strength of these linkages and reinforce assertions of causality.

\section{APPENDIX A: CHINESE DOMESTIC MODEL}

\section{APPENDIX TABLE A.1}

Variable Definitions

\begin{tabular}{|c|c|}
\hline Variables & Definition \\
\hline$L L P C C_{t-1}$ & Logarithm of the ratio of cotton price to corn price, one lag \\
\hline$L L P C S C_{t-1}$ & Logarithm of the ratio of cotton price to competing crop price (soybean and corn prices), one lag \\
\hline$L_{L P C R S_{t-1}}$ & Logarithm of the ratio of cotton price to competing crop price (rice and soybean prices), one lag \\
\hline$L L H A C_{t-1}$ & Logarithm of lag of cotton area \\
\hline$D_{79-82}$ & If year is between 1979 and $1982, D_{79-82}=1$; otherwise $D_{79-82}=0$ \\
\hline$D_{86-93}$ & If year is between 1986 and $1993, D_{86-93}=1$; otherwise $D_{86-93}=0$ \\
\hline$T R E N D$ & Time trend \\
\hline LTREND & Logarithm of time trend \\
\hline$L P P_{t-\mathrm{i}}$ & Weighted average of polyester price from 3 to 7 period lags \\
\hline$L R P_{t-\mathrm{i}}$ & Weighted average of rayon price from 3 to 7 period lags \\
\hline$L O P_{t-\mathrm{i}}$ & Weighted average of oil price from 3 to 7 period lags \\
\hline$L C A P_{t-1}$ & Manmade fiber capacity lagged one year \\
\hline$P R O$ & Ratio of rayon price to oil price \\
\hline$P P O$ & Ratio of polyester price to oil price \\
\hline$L U T L_{t-1}$ & Lag of manmade fiber capacity utilization rate \\
\hline$G D P$ & Per capita income \\
\hline$L G D P$ & Logarithm of per capita income \\
\hline$L T P I$ & Logarithm of textile price index \\
\hline LFPI & Logarithm of food price index \\
\hline$L C U A P I$ & $\begin{array}{l}\text { Logarithm of Chinese apparel price index with respect to U.S. apparel price index times Chinese } \\
\text { exchange rate }\end{array}$ \\
\hline TXOUT & Logarithm of textile fiber expenditure with respect to the price index (equation 7) \\
\hline$C P$ & Cotton domestic price \\
\hline$L C P$ & Logarithm of cotton domestic price \\
\hline$L W P$ & Logarithm of wool domestic price \\
\hline$L M M P$ & Logarithm of manmade fiber domestic price \\
\hline$C P W D$ & Ratio of world price (A-index) expressed in domestic currency to Chinese domestic cotton price \\
\hline$Q C P W D$ & A-index converted to Chinese currency plus the import tariffs \\
\hline$L D M P_{t-1}$ & Ratio of previous year's Chinese domestic cotton mill use to production \\
\hline$C D S P$ & Cotton domestic supply \\
\hline
\end{tabular}

APPENDIX TABLE A.2

Parameter Estimates of Chinese Fiber Model

\begin{tabular}{|c|c|c|c|c|}
\hline Equations & & Adj. $R^{2}$ & $\begin{array}{l}\text { D-W } \\
\text { Statistics }\end{array}$ & $\begin{array}{c}F- \\
\text { Statistics }\end{array}$ \\
\hline \multicolumn{5}{|l|}{ Cotton acreage } \\
\hline (1.1) Northwest & $\begin{array}{c}=-0.53+0.22 * L L P C C_{t-1}+0.99 * L L H A C_{t-1}+0.11 * D_{79-82}+0.10 * D_{86-93} \\
(0.25)(0.12)\end{array}$ & 0.95 & 2.02 & 270.38 \\
\hline (1.2) Yellow River & $\begin{array}{c}=1.93+0.21 * L_{L P C S C_{t-1}}+0.73 * L L H A C_{t-1}+0.24 * D_{79-82}+0.13 * D_{86-93} \\
(1.54)(0.17)\end{array}$ & 0.83 & 1.69 & 12.31 \\
\hline (1.3) Yangtze River & $\begin{array}{c}=0.96+0.22 * L L P C R S_{t-1}+0.80 * L L H A C_{t-1}+0.05 * D_{79-82}+0.13 * D_{86-93} \\
(1.13)(0.12)\end{array}$ & 0.72 & 1.91 & 5.97 \\
\hline (1.4) Rest of China & $\begin{array}{c}=-1.33+0.29^{*} L L P C R S_{t-1}+0.78^{*} L L H A C_{t-1}-0.06^{*} D_{79-82}+0.08^{*} D_{86-93} \\
\quad(0.71)(0.60)\end{array}$ & 0.84 & 1.89 & 15.23 \\
\hline
\end{tabular}


APPENDIX TABLE A.2 continued

\begin{tabular}{|c|c|c|c|c|}
\hline Equations & & Adj. $R^{2}$ & $\begin{array}{c}\text { D-W } \\
\text { Statistics }\end{array}$ & $\begin{array}{c}F- \\
\text { Statistics }\end{array}$ \\
\hline \multicolumn{5}{|l|}{ Cotton yield } \\
\hline (1.5) Northwest & $\begin{array}{c}=-1.76+0.07^{*} L L P C C_{t-1}+0.62^{*} T R E N D \\
(0.27)(0.04)\end{array}$ & 0.92 & 1.69 & 96.34 \\
\hline (1.6) Yellow River & $\begin{aligned}= & 0.97+0.02 * L L P C S C_{t-1}+0.62 * T R E N D \\
& (0.17)(0.03)\end{aligned}$ & 0.69 & 1.75 & 22.48 \\
\hline (1.7) Yangtze River & $\begin{array}{c}=-0.75+0.05^{*} L L P C R C_{t-1}+0.03 * T R E N D \\
\quad(0.27)(0.10)\end{array}$ & 0.79 & 1.73 & 9.90 \\
\hline (1.8) Rest of China & 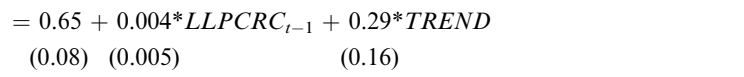 & 0.35 & 2.34 & 206 \\
\hline \multicolumn{5}{|l|}{ Manmade fiber production } \\
\hline (1.9) Synthetics capacity & $\begin{array}{l}=5.67+0.24^{*} L P P_{t-\mathrm{i}}-0.55^{*} L O P_{t-\mathrm{i}}+1.87^{*} T R E N D \\
\left(\begin{array}{lll}(0.29) & (0.24) & (0.06)\end{array}\right.\end{array}$ & 0.95 & 2.28 & \\
\hline (1.10) Utilization rate & $\begin{array}{l}=-0.82+0.40 * P P O+1.99 * L U T L_{t-1} \\
\quad(1.73)(0.19) \quad(0.69)\end{array}$ & 0.78 & 1.86 & \\
\hline $\begin{array}{l}\text { (1.11) Cellulosics } \\
\text { capacity }\end{array}$ & $\begin{array}{l}=0.91+0.27^{*} L R P_{t-i}-0.07^{*} L O P_{t-\mathrm{i}}+0.77^{*} L C A P_{t-1} \\
(0.44)(0.09)\end{array}$ & 0.92 & 1.92 & \\
\hline (1.12) Utilization rate & $\begin{aligned}= & 2.28+0.22 * P R O+3.94 * L U T L_{t-1} \\
& (1.21)(0.59)\end{aligned}$ & 0.83 & 1.82 & \\
\hline \multicolumn{5}{|l|}{ Fiber demand } \\
\hline $\begin{array}{l}\text { (1.13) Textile } \\
\text { consumption }\end{array}$ & $\begin{aligned}= & 3.5+1.15^{*} L G D P-0.47^{*} L T P I+0.06^{*} L F P I \\
& (0.69)(0.05)\end{aligned}$ & 0.81 & 1.76 & \\
\hline (1.14) Textile net trade & $\begin{aligned}= & 6.34-0.51 * L C A U P I+0.44 * \log (\text { TREND }) \\
& (0.07)(0.16)\end{aligned}$ & 0.85 & 1.90 & \\
\hline $\begin{array}{l}\text { (1.15) Cotton share in } \\
\text { fiber mill use }\end{array}$ & $\begin{aligned}= & 3.67-0.39^{*} \text { TXOUT }+0.11^{*} L C P-0.04^{*} L W P-0.07^{*} L M M P \\
& (0.84)(0.10)\end{aligned}$ & 0.82 & 1.81 & \\
\hline $\begin{array}{l}\text { (1.16) Manmade fiber } \\
\text { share in mill use }\end{array}$ & $\begin{array}{c}=-2.53+0.36^{*} T X O U T+0.36^{*} L C P-0.07^{*} L W P+0.07^{*} L M M P \\
(0.84)(0.10)\end{array}$ & 0.81 & 1.87 & \\
\hline $\begin{array}{l}\text { (1.17) Cotton ending } \\
\text { stock }\end{array}$ & $\begin{array}{c}=-7.97+1.88 * C D S P-0.89 * C P \\
(1.07)(0.12)\end{array}$ & 0.86 & 1.79 & \\
\hline (1.18) Cotton imports & $\begin{array}{c}=-144.74-21.05^{*} C P W D+7.36^{*} G D P \\
(5.32) \quad(7.69)\end{array}$ & 0.75 & 1.87 & \\
\hline (1.19) Cotton exports & $\begin{aligned}= & 5.07+1.93^{*} C P W D-3.80^{*} L D M P_{t-1} \\
& (0.23)(0.99)\end{aligned}$ & 0.81 & 1.96 & \\
\hline
\end{tabular}

APPENDIX TABLE A.3

Chinese Fiber Supply Elasticities

\begin{tabular}{|c|c|c|}
\hline & \multicolumn{2}{|c|}{ With Respect to the Price of } \\
\hline & Cotton & Manmade Fiber \\
\hline \multicolumn{3}{|c|}{ Cotton acreage response } \\
\hline Yellow River & 0.11 & \\
\hline Yangtze River & 0.10 & \\
\hline Northwest & 0.20 & \\
\hline \multicolumn{3}{|c|}{ Manmade fiber production } \\
\hline Synthetics & & 0.36 \\
\hline Cellulosics & & 0.14 \\
\hline
\end{tabular}

APPENDIX TABLE A.4

Chinese Fiber Demand Elasticities

\begin{tabular}{|c|c|c|c|c|}
\hline & \multirow[b]{2}{*}{$\begin{array}{c}\text { Income } \\
\text { Elasticity }\end{array}$} & \multicolumn{3}{|c|}{$\begin{array}{l}\text { With Respect to the } \\
\text { Price of }\end{array}$} \\
\hline & & Cotton & $\begin{array}{c}\text { Manmade } \\
\text { Fiber }\end{array}$ & Wool \\
\hline $\begin{array}{l}\text { Per capita fiber } \\
\text { consumption }\end{array}$ & 1.15 & & & \\
\hline Cotton & & -0.33 & 0.38 & -0.05 \\
\hline Manmade fiber & & 0.28 & -0.32 & 0.04 \\
\hline Wool & & -0.33 & 0.40 & -0.07 \\
\hline
\end{tabular}


APPENDIX TABLE A.5

Mean Square Error Decompositions and Theil $U$-Statistics

\begin{tabular}{lcccccc}
\hline & Bias & Reg & Dist & Var & Covar & Theil $\boldsymbol{U}$-Statistics \\
\cline { 2 - 5 } Variable & $\mathbf{( U M )}$ & $\mathbf{( U R )}$ & $\mathbf{( U D )}$ & $\mathbf{( U S )}$ & $\mathbf{( U C )}$ & 0.014 \\
\hline Chinese cotton price & 0.052 & 0.023 & 0.925 & 0.000 & 0.948 & 0.058 \\
Chinese polyester price & 0.034 & 0.040 & 0.926 & 0.000 & 0.966 & 0.084 \\
Chinese Northwest area & 0.090 & 0.064 & 0.846 & 0.038 & 0.872 & 0.073 \\
Chinese Yellow River area & 0.010 & 0.026 & 0.964 & 0.066 & 0.924 & 0.011 \\
Chinese Yangtze River area & 0.000 & 0.020 & 0.980 & 0.058 & 0.942 & 0.040 \\
Chinese Northwest yield & 0.020 & 0.034 & 0.946 & 0.010 & 0.970 & 0.100 \\
Chinese Yellow River yield & 0.019 & 0.077 & 0.904 & 0.081 & 0.900 & 0.046 \\
Chinese Yangtze River yield & 0.000 & 0.170 & 0.830 & 0.071 & 0.929 & 0.030 \\
Chinese cotton imports & 0.040 & 0.010 & 0.950 & 0.064 & 0.896 & 0.057 \\
Chinese cotton exports & 0.030 & 0.060 & 0.910 & 0.021 & 0.949 & 0.062 \\
Chinese cotton mill use & 0.051 & 0.025 & 0.924 & 0.036 & 0.913 & 0.025 \\
Chinese cotton ending stock & 0.020 & 0.041 & 0.939 & 0.060 & 0.920 & 0.120 \\
Chinese domestic fiber consumption & 0.020 & 0.074 & 0.906 & 0.050 & 0.930 & 0.081 \\
Chinese cotton mill use & 0.017 & 0.043 & 0.940 & 0.110 & 0.873 & 0.068 \\
Chinese synthetic capacity & 0.022 & 0.047 & 0.931 & 0.054 & 0.924 & 0.013 \\
Chinese synthetic itilization & 0.048 & 0.070 & 0.882 & 0.030 & 0.922 & 0.094 \\
Chinese cellulosic capacity & 0.064 & 0.020 & 0.916 & 0.020 & 0.916 & 0.054 \\
Chinese cellulosic utilization & 0.024 & 0.044 & 0.932 & 0.054 & 0.922 & 0.200 \\
Chinese manmade fiber mill use & 0.040 & 0.075 & 0.885 & 0.050 & 0.910 & 0.104 \\
Chinese total fiber mill use & 0.020 & 0.071 & 0.909 & 0.047 & 0.933 & 0.034 \\
Chinese total fiber net exports & 0.021 & 0.033 & 0.946 & 0.022 & 0.957 & 0.040 \\
Chinese textile price index & 0.060 & 0.050 & 0.890 & 0.190 & 0.750 & \\
\hline
\end{tabular}

\section{APPENDIX B: WORLD FIBER MODEL}

The world fiber model includes 24 major cotton importers and exporters: (1) Asia (India, Pakistan, Taiwan, South Korea, Japan, and Other Asia); (2) Africa (Egypt, Western Africa, and Other Africa); (3) North America (Mexico, United States, and Canada); (4) Latin America (Brazil, Argentina, and Other Latin America); (5) Oceania (Australia); (6) Middle East (Turkey and Other Middle East); (6) Former Soviet Union (Uzbekistan, Russia, and Other FSU); (7) Europe (European Union, Central and Eastern Europe, and Other Western Europe). Its structure is similar in many ways to that of the Chinese model presented in the main text.

As shown in Figure B.1, the world fiber model includes supply, demand, and market equilibrium for both cotton and manmade fibers. Cotton production in each country and region defined in the model is derived from behavioral equations of area and yield. Generally, the acreage equation is specified as a function of the expected net returns for cotton and competing crops whereas yield is dependent on expected cotton price and a time trend, which is used to account for technological development in crop production. In some instances, expected prices are used in lieu of expected net return due to nonavailability of cost of production data. For geographically large cotton-producing nations with heterogeneous growing conditions, such as the United States and India, cotton production is estimated in a regional framework to capture regional differ- ences in climate, water availability, and other natural resources that influence crop planting decisions in different parts of each country.

For the manmade fiber supply sector, production is derived from estimates of capacity and utilization. Production capacity for manmade fibers (cellulosics and synthetics) are dependent on past or lagged input and output prices (i.e., petroleum and polyester/rayon prices, respectively) whereas utilization rates are derived from more recent input and output prices. The lag length is determined by using the minimum AIC method.

The textile sector in the model is used to determine the mill use of each fiber (cotton, manmade fiber, and wool). It is estimated using a two-step process. In the first step, total fiber demand (cotton, wool, and manmade) is calculated by summing fiber demand in apparel, home furnishing, floor covering, and other industrial sectors. The elasticities are estimated by the real GDP per capita and domestic textile price indices. The net trade equation is estimated by a textile price index comparison between domestic and international textile prices. Mill use is derived from the domestic fiber consumption and net trade of textiles. In the second step, total fiber production is divided among cotton, manmade, and wool fibers based on the relative price of each as well as other nonprice factors. Full documentation of the world fiber model is presented in Pan et al. (2004) or accessible online at www.ceri.ttu. edu/policy. 


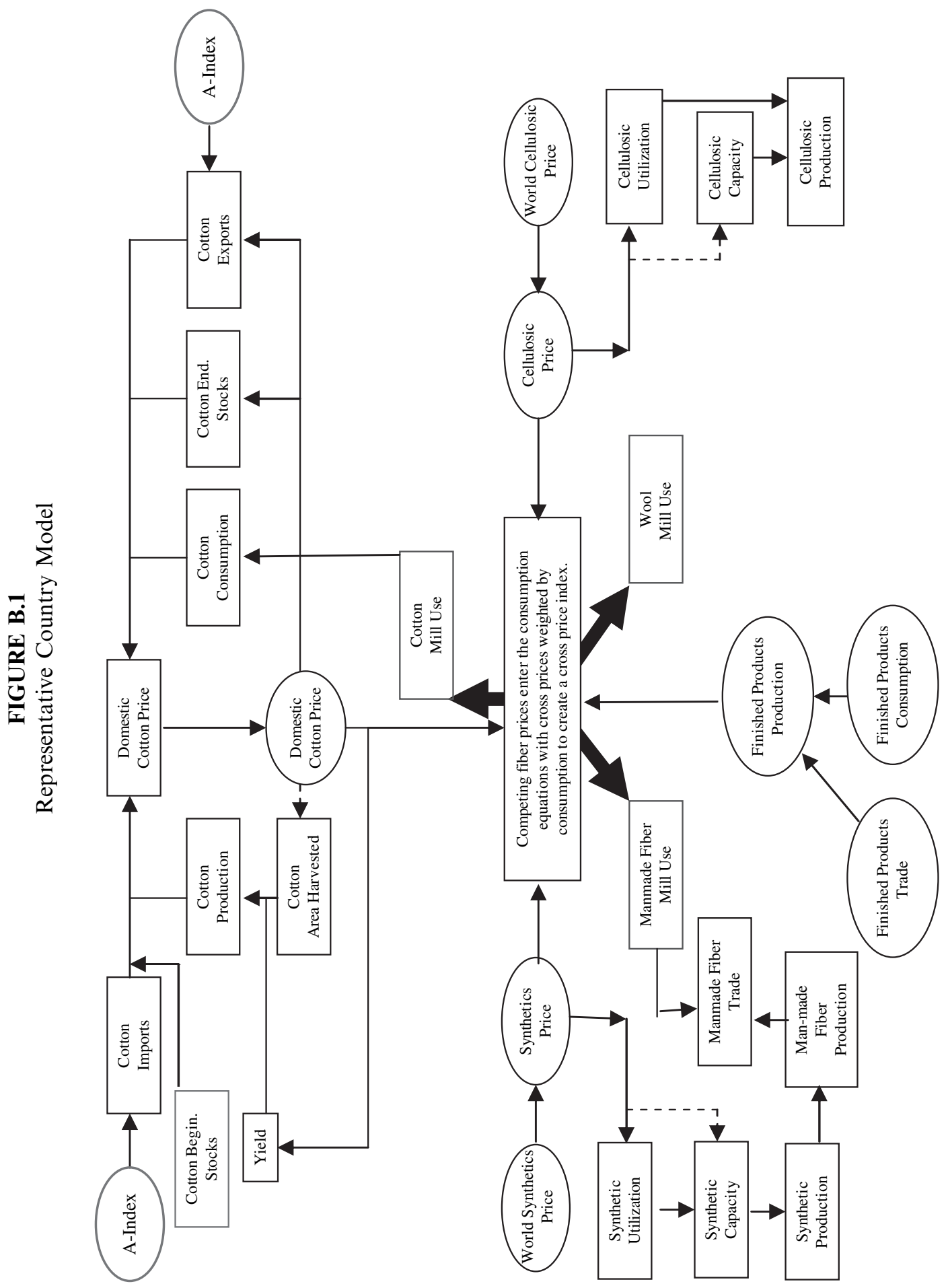


APPENDIX TABLE C.1

Effects of RMB Revaluation on Chinese Fiber Markets

\begin{tabular}{|c|c|c|c|c|c|c|c|c|c|c|c|c|}
\hline & & $2005 / 6$ & $2006 / 7$ & $2007 / 8$ & $2008 / 9$ & $2009 / 10$ & $2010 / 11$ & 2011/12 & $2012 / 13$ & $2013 / 14$ & $2014 / 15$ & Average \\
\hline \multicolumn{13}{|l|}{ Cotton } \\
\hline \multirow[t]{5}{*}{ Imports } & Base (000MT) & 2962.20 & 3018.44 & 3122.38 & 3131.87 & 3204.06 & 3295.99 & 3303.78 & 3312.94 & 3319.08 & 3359.54 & 3203.03 \\
\hline & $2 \%$ appreciation & $0.68 \%$ & $0.94 \%$ & $0.83 \%$ & $0.80 \%$ & $0.80 \%$ & $0.77 \%$ & $0.74 \%$ & $0.72 \%$ & $0.71 \%$ & $0.68 \%$ & $0.77 \%$ \\
\hline & $5 \%$ appreciation & $1.08 \%$ & $1.61 \%$ & $1.46 \%$ & $1.39 \%$ & $1.36 \%$ & $1.26 \%$ & $1.14 \%$ & $1.01 \%$ & $0.94 \%$ & $0.83 \%$ & $1.21 \%$ \\
\hline & $15 \%$ appreciation & $3.91 \%$ & $5.02 \%$ & $4.85 \%$ & $4.63 \%$ & $4.49 \%$ & $4.23 \%$ & $4.10 \%$ & $3.97 \%$ & $3.68 \%$ & $3.09 \%$ & $4.20 \%$ \\
\hline & $5 \%$ depreciation & $-1.03 \%$ & $-1.60 \%$ & $-1.44 \%$ & $-1.38 \%$ & $-1.35 \%$ & $-1.25 \%$ & $-1.13 \%$ & $-0.98 \%$ & $-0.94 \%$ & $-0.83 \%$ & $-1.19 \%$ \\
\hline \multirow[t]{5}{*}{ Mill use } & Base (000MT) & 8554.49 & 8753.66 & 9044.96 & 9252.66 & 9528.52 & 9693.55 & 9881.76 & 9823.45 & 9923.05 & 9991.92 & 9444.80 \\
\hline & $2 \%$ appreciation & $-0.04 \%$ & $-0.09 \%$ & $-0.09 \%$ & $-0.06 \%$ & $-0.03 \%$ & $-0.03 \%$ & $-0.02 \%$ & $-0.01 \%$ & $-0.01 \%$ & $-0.01 \%$ & $-0.04 \%$ \\
\hline & $5 \%$ appreciation & $-0.10 \%$ & $-0.22 \%$ & $-0.23 \%$ & $-0.15 \%$ & $-0.09 \%$ & $-0.07 \%$ & $-0.05 \%$ & $-0.03 \%$ & $-0.03 \%$ & $-0.03 \%$ & $-0.10 \%$ \\
\hline & $15 \%$ appreciation & $-0.32 \%$ & $-0.65 \%$ & $-0.70 \%$ & $-0.48 \%$ & $-0.28 \%$ & $-0.22 \%$ & $-0.18 \%$ & $-0.12 \%$ & $-0.11 \%$ & $-0.11 \%$ & $-0.32 \%$ \\
\hline & $5 \%$ depreciation & $0.11 \%$ & $0.21 \%$ & $0.22 \%$ & $0.14 \%$ & $0.09 \%$ & $0.07 \%$ & $0.05 \%$ & $0.03 \%$ & $0.03 \%$ & $0.03 \%$ & $0.10 \%$ \\
\hline \multirow[t]{5}{*}{ Production } & Base (000MT) & 5660.89 & 5807.92 & 6145.40 & 6311.37 & 6503.49 & 6636.80 & 6730.94 & 6750.07 & 6884.21 & 6786.01 & 6421.71 \\
\hline & $2 \%$ appreciation & $0.00 \%$ & $-0.63 \%$ & $-0.72 \%$ & $-0.57 \%$ & $-0.33 \%$ & $-0.31 \%$ & $-0.24 \%$ & $-0.16 \%$ & $-0.13 \%$ & $-0.10 \%$ & $-0.32 \%$ \\
\hline & $5 \%$ appreciation & $0.00 \%$ & $-1.52 \%$ & $-1.74 \%$ & $-1.19 \%$ & $-0.75 \%$ & $-0.69 \%$ & $-0.55 \%$ & $-0.47 \%$ & $-0.46 \%$ & $-0.39 \%$ & $-0.78 \%$ \\
\hline & $15 \%$ appreciation & $0.00 \%$ & $-5.77 \%$ & $-6.03 \%$ & $-3.47 \%$ & $-2.79 \%$ & $-1.39 \%$ & $-3.05 \%$ & $-2.51 \%$ & $-1.76 \%$ & $-1.13 \%$ & $-2.79 \%$ \\
\hline & $5 \%$ depreciation & $0.00 \%$ & $1.49 \%$ & $1.71 \%$ & $1.17 \%$ & $0.74 \%$ & $0.63 \%$ & $0.53 \%$ & $0.43 \%$ & $0.42 \%$ & $0.35 \%$ & $0.75 \%$ \\
\hline \multicolumn{13}{|c|}{ Manmade fiber net imports } \\
\hline & Base $(000 \mathrm{MT})$ & 1070.18 & 1289.96 & 1203.31 & 1315.97 & 1319.90 & 1520.41 & 1361.64 & 1409.99 & 1374.37 & 1170.42 & 1303.61 \\
\hline & $2 \%$ appreciation & $0.25 \%$ & $0.38 \%$ & $0.44 \%$ & $0.49 \%$ & $0.57 \%$ & $0.69 \%$ & $0.74 \%$ & $0.80 \%$ & $0.86 \%$ & $0.94 \%$ & $0.61 \%$ \\
\hline & $5 \%$ appreciation & $0.73 \%$ & $0.74 \%$ & $0.86 \%$ & $0.99 \%$ & $1.18 \%$ & $1.58 \%$ & $1.75 \%$ & $1.89 \%$ & $2.07 \%$ & $2.28 \%$ & $1.41 \%$ \\
\hline & $15 \%$ appreciation & $2.22 \%$ & $2.20 \%$ & $2.62 \%$ & $3.00 \%$ & $3.54 \%$ & $4.70 \%$ & $5.26 \%$ & $5.68 \%$ & $6.34 \%$ & $6.53 \%$ & $4.21 \%$ \\
\hline & $5 \%$ depreciation & $-0.71 \%$ & $-0.71 \%$ & $-0.84 \%$ & $-0.98 \%$ & $-1.16 \%$ & $-1.57 \%$ & $-1.74 \%$ & $-1.88 \%$ & $-2.06 \%$ & $-2.27 \%$ & $-1.39 \%$ \\
\hline \multicolumn{13}{|c|}{ Textile exports } \\
\hline & Base (000MT) & 5660.89 & 5807.92 & 6145.40 & 6311.37 & 6503.49 & 6636.80 & 6730.94 & 6750.07 & 6884.21 & 6786.01 & 6421.71 \\
\hline & $2 \%$ appreciation & $-0.81 \%$ & $-0.79 \%$ & $-0.97 \%$ & $-1.02 \%$ & $-1.06 \%$ & $-1.04 \%$ & $-1.05 \%$ & $-1.19 \%$ & $-1.34 \%$ & $-1.38 \%$ & $-1.06 \%$ \\
\hline & $5 \%$ appreciation & $-2.21 \%$ & $-2.19 \%$ & $-2.47 \%$ & $-2.55 \%$ & $-2.56 \%$ & $-2.49 \%$ & $-2.45 \%$ & $-2.52 \%$ & $-2.62 \%$ & $-2.62 \%$ & $-2.47 \%$ \\
\hline & $15 \%$ appreciation & $-6.93 \%$ & $-7.01 \%$ & $-7.68 \%$ & $-7.77 \%$ & $-7.72 \%$ & $-7.22 \%$ & $-7.16 \%$ & $-7.09 \%$ & $-6.87 \%$ & $-6.61 \%$ & $-7.21 \%$ \\
\hline & $5 \%$ depreciation & $2.89 \%$ & $2.88 \%$ & $2.98 \%$ & $2.82 \%$ & $2.69 \%$ & $2.62 \%$ & $2.50 \%$ & $2.21 \%$ & $1.95 \%$ & $1.81 \%$ & $2.53 \%$ \\
\hline \multicolumn{13}{|c|}{ Domestic cotton price } \\
\hline & Base (yuan/lb) & 7.20 & 7.28 & 7.42 & 7.59 & 7.84 & 7.86 & 7.96 & 8.25 & 8.27 & 8.28 & 7.80 \\
\hline & $2 \%$ appreciation & $-2.71 \%$ & $-2.29 \%$ & $-1.98 \%$ & $-0.59 \%$ & $-0.68 \%$ & $-1.23 \%$ & $-1.12 \%$ & $-0.83 \%$ & $-0.76 \%$ & $-0.95 \%$ & $-1.32 \%$ \\
\hline & $5 \%$ appreciation & $-4.70 \%$ & $-4.58 \%$ & $-3.80 \%$ & $-2.56 \%$ & $-2.22 \%$ & $-2.00 \%$ & $-2.15 \%$ & $-2.06 \%$ & $-1.42 \%$ & $-1.41 \%$ & $-2.69 \%$ \\
\hline & $15 \%$ appreciation & $-10.25 \%$ & $-9.45 \%$ & $-6.65 \%$ & $-6.26 \%$ & $-5.73 \%$ & $-5.40 \%$ & $-4.84 \%$ & $-4.38 \%$ & $-3.83 \%$ & $-3.71 \%$ & $-6.05 \%$ \\
\hline & $5 \%$ depreciation & $5.06 \%$ & $4.68 \%$ & $3.67 \%$ & $2.19 \%$ & $1.99 \%$ & $1.98 \%$ & $1.98 \%$ & $1.97 \%$ & $1.40 \%$ & $1.30 \%$ & $2.62 \%$ \\
\hline
\end{tabular}


APPENDIX TABLE C.2

Effects of RMB Revaluation on World Fiber Markets

\begin{tabular}{|c|c|c|c|c|c|c|c|c|c|c|c|c|}
\hline & & $2005 / 6$ & $2006 / 7$ & $2007 / 8$ & $2008 / 9$ & $2009 / 10$ & $2010 / 11$ & $2011 / 12$ & $2012 / 13$ & $2013 / 14$ & $2014 / 15$ & Average \\
\hline \multirow[t]{5}{*}{ A-index } & Base (cents/lb) & 58.58 & 62.19 & 63.28 & 63.91 & 64.03 & 64.23 & 66.39 & 67.78 & 67.87 & 68.00 & 64.63 \\
\hline & $2 \%$ appreciation & $0.04 \%$ & $0.08 \%$ & $0.13 \%$ & $0.13 \%$ & $0.16 \%$ & $0.17 \%$ & $0.19 \%$ & $0.22 \%$ & $0.30 \%$ & $0.32 \%$ & $0.17 \%$ \\
\hline & $5 \%$ appreciation & $0.11 \%$ & $0.24 \%$ & $0.32 \%$ & $0.32 \%$ & $0.37 \%$ & $0.37 \%$ & $0.41 \%$ & $0.44 \%$ & $0.49 \%$ & $0.54 \%$ & $0.36 \%$ \\
\hline & $15 \%$ appreciation & $0.48 \%$ & $0.59 \%$ & $0.69 \%$ & $0.85 \%$ & $1.31 \%$ & $1.53 \%$ & $1.55 \%$ & $1.58 \%$ & $1.66 \%$ & $1.66 \%$ & $1.19 \%$ \\
\hline & $5 \%$ depreciation & $-0.10 \%$ & $-0.22 \%$ & $-0.32 \%$ & $-0.32 \%$ & $-0.35 \%$ & $-0.37 \%$ & $-0.39 \%$ & $-0.41 \%$ & $-0.47 \%$ & $-0.53 \%$ & $-0.35 \%$ \\
\hline \multirow[t]{5}{*}{ Polyester price } & Base (cents/lb) & 61.93 & 63.06 & 63.08 & 63.14 & 65.35 & 66.02 & 67.11 & 68.11 & 68.63 & 68.78 & 65.52 \\
\hline & $2 \%$ appreciation & $0.14 \%$ & $0.19 \%$ & $0.19 \%$ & $0.20 \%$ & $0.34 \%$ & $0.37 \%$ & $0.45 \%$ & $0.48 \%$ & $0.53 \%$ & $0.53 \%$ & $0.34 \%$ \\
\hline & $5 \%$ appreciation & $0.31 \%$ & $0.40 \%$ & $0.41 \%$ & $0.42 \%$ & $0.66 \%$ & $0.73 \%$ & $0.85 \%$ & $0.91 \%$ & $1.01 \%$ & $1.18 \%$ & $0.69 \%$ \\
\hline & $15 \%$ appreciation & $0.87 \%$ & $0.99 \%$ & $1.28 \%$ & $1.29 \%$ & $1.52 \%$ & $2.04 \%$ & $2.40 \%$ & $2.89 \%$ & $3.02 \%$ & $3.21 \%$ & $1.95 \%$ \\
\hline & $5 \%$ depreciation & $-0.35 \%$ & $-0.42 \%$ & $-0.43 \%$ & $-0.46 \%$ & $-0.67 \%$ & $-1.27 \%$ & $-1.30 \%$ & $-1.47 \%$ & $-1.60 \%$ & $-1.95 \%$ & $-0.99 \%$ \\
\hline World cotton & Base (000MT) & 8491.59 & 8304.28 & 8628.45 & 8974.60 & 9350.34 & 9785.79 & 10062.50 & 10278.95 & 10382.73 & 10514.11 & 9477.33 \\
\hline \multirow[t]{4}{*}{ Trade } & $2 \%$ appreciation & $0.05 \%$ & $0.12 \%$ & $0.12 \%$ & $0.14 \%$ & $0.16 \%$ & $0.19 \%$ & $0.20 \%$ & $0.27 \%$ & $0.33 \%$ & $0.40 \%$ & $0.20 \%$ \\
\hline & $5 \%$ appreciation & $0.12 \%$ & $0.21 \%$ & $0.23 \%$ & $0.25 \%$ & $0.30 \%$ & $0.31 \%$ & $0.39 \%$ & $0.40 \%$ & $0.47 \%$ & $0.58 \%$ & $0.32 \%$ \\
\hline & $15 \%$ appreciation & $0.36 \%$ & $0.59 \%$ & $0.63 \%$ & $0.71 \%$ & $0.84 \%$ & $0.95 \%$ & $1.08 \%$ & $1.15 \%$ & $1.49 \%$ & $1.64 \%$ & $0.94 \%$ \\
\hline & $5 \%$ depreciation & $-0.11 \%$ & $-0.20 \%$ & $-0.21 \%$ & $-0.23 \%$ & $-0.29 \%$ & $-0.30 \%$ & $-0.35 \%$ & $-0.38 \%$ & $-0.41 \%$ & $-0.51 \%$ & $-0.30 \%$ \\
\hline \multicolumn{13}{|l|}{ Major exporters } \\
\hline \multirow[t]{5}{*}{ United States } & Base (000MT) & 2743.88 & 2934.86 & 2933.01 & 2959.33 & 2962.78 & 3016.46 & 3026.35 & 3086.61 & 3096.22 & 3188.92 & 2994.84 \\
\hline & $2 \%$ appreciation & $0.13 \%$ & $0.11 \%$ & $0.10 \%$ & $0.09 \%$ & $0.09 \%$ & $0.08 \%$ & $0.07 \%$ & $0.07 \%$ & $0.07 \%$ & $0.07 \%$ & $0.09 \%$ \\
\hline & $5 \%$ appreciation & $0.32 \%$ & $0.28 \%$ & $0.23 \%$ & $0.22 \%$ & $0.16 \%$ & $0.15 \%$ & $0.13 \%$ & $0.12 \%$ & $0.11 \%$ & $0.11 \%$ & $0.18 \%$ \\
\hline & $15 \%$ appreciation & $0.72 \%$ & $0.61 \%$ & $0.48 \%$ & $0.50 \%$ & $0.46 \%$ & $0.45 \%$ & $0.43 \%$ & $0.36 \%$ & $0.32 \%$ & $0.30 \%$ & $0.46 \%$ \\
\hline & $5 \%$ depreciation & $-0.26 \%$ & $-0.23 \%$ & $-0.20 \%$ & $-0.19 \%$ & $-0.16 \%$ & $-0.13 \%$ & $-0.13 \%$ & $-0.11 \%$ & $-0.11 \%$ & $-0.11 \%$ & $-0.16 \%$ \\
\hline \multirow[t]{5}{*}{ Brazil } & Base (000MT) & 440.87 & 617.79 & 835.53 & 1055.39 & 1316.40 & 1585.75 & 1718.92 & 1753.50 & 1817.40 & 1854.81 & 1299.64 \\
\hline & $2 \%$ appreciation & $0.35 \%$ & $0.53 \%$ & $0.61 \%$ & $0.63 \%$ & $0.64 \%$ & $0.66 \%$ & $0.68 \%$ & $0.68 \%$ & $0.72 \%$ & $0.74 \%$ & $0.63 \%$ \\
\hline & $5 \%$ appreciation & $0.69 \%$ & $1.03 \%$ & $1.12 \%$ & $1.60 \%$ & $1.77 \%$ & $1.86 \%$ & $1.90 \%$ & $1.90 \%$ & $1.93 \%$ & $1.94 \%$ & $1.57 \%$ \\
\hline & $15 \%$ appreciation & $2.05 \%$ & $2.95 \%$ & $3.22 \%$ & $4.65 \%$ & $5.15 \%$ & $5.36 \%$ & $5.51 \%$ & $5.68 \%$ & $5.76 \%$ & $5.83 \%$ & $4.62 \%$ \\
\hline & $5 \%$ depreciation & $-0.64 \%$ & $-1.03 \%$ & $-1.10 \%$ & $-1.49 \%$ & $-1.74 \%$ & $-1.79 \%$ & $-1.85 \%$ & $-1.90 \%$ & $-1.93 \%$ & $-1.94 \%$ & $-1.54 \%$ \\
\hline \multirow[t]{5}{*}{ Australia } & Base (000MT) & 673.26 & 675.90 & 710.25 & 730.53 & 744.38 & 758.05 & 771.44 & 777.64 & 786.09 & 798.54 & 742.61 \\
\hline & $2 \%$ appreciation & $0.17 \%$ & $0.19 \%$ & $0.20 \%$ & $0.25 \%$ & $0.26 \%$ & $0.28 \%$ & $0.28 \%$ & $0.30 \%$ & $0.33 \%$ & $0.37 \%$ & $0.26 \%$ \\
\hline & $5 \%$ appreciation & $0.38 \%$ & $0.34 \%$ & $0.53 \%$ & $0.54 \%$ & $0.55 \%$ & $0.63 \%$ & $0.64 \%$ & $0.88 \%$ & $0.97 \%$ & $1.11 \%$ & $0.66 \%$ \\
\hline & $15 \%$ appreciation & $0.94 \%$ & $1.18 \%$ & $1.65 \%$ & $1.75 \%$ & $1.78 \%$ & $1.87 \%$ & $1.93 \%$ & $1.95 \%$ & $2.13 \%$ & $2.31 \%$ & $1.75 \%$ \\
\hline & $5 \%$ depreciation & $-0.27 \%$ & $-0.30 \%$ & $-0.48 \%$ & $-0.50 \%$ & $-0.52 \%$ & $-0.61 \%$ & $-0.63 \%$ & $-0.72 \%$ & $-0.91 \%$ & $-0.99 \%$ & $-0.59 \%$ \\
\hline
\end{tabular}


APPENDIX TABLE C.2 continued

\begin{tabular}{|c|c|c|c|c|c|c|c|c|c|c|c|c|}
\hline & & $2005 / 6$ & $2006 / 7$ & $2007 / 8$ & $2008 / 9$ & $2009 / 10$ & 2010/11 & 2011/12 & $2012 / 13$ & $2013 / 14$ & $2014 / 15$ & Average \\
\hline \multicolumn{13}{|c|}{ Major importers } \\
\hline \multirow[t]{5}{*}{ Mexico } & Base (000MT) & 263.54 & 313.81 & 354.55 & 396.67 & 416.64 & 453.30 & 476.62 & 534.54 & 568.40 & 638.22 & 441.63 \\
\hline & $2 \%$ appreciation & $-0.41 \%$ & $-0.33 \%$ & $-0.22 \%$ & $-0.19 \%$ & $-0.13 \%$ & $-0.12 \%$ & $-0.11 \%$ & $-0.09 \%$ & $-0.09 \%$ & $-0.08 \%$ & $-0.18 \%$ \\
\hline & $5 \%$ appreciation & $-0.79 \%$ & $-0.66 \%$ & $-0.49 \%$ & $-0.36 \%$ & $-0.28 \%$ & $-0.25 \%$ & $-0.24 \%$ & $-0.19 \%$ & $-0.16 \%$ & $-0.14 \%$ & $-0.36 \%$ \\
\hline & $15 \%$ appreciation & $-2.33 \%$ & $-1.75 \%$ & $-1.46 \%$ & $-1.27 \%$ & $-0.64 \%$ & $-0.56 \%$ & $-0.50 \%$ & $-0.46 \%$ & $-0.45 \%$ & $-0.60 \%$ & $-1.00 \%$ \\
\hline & $5 \%$ depreciation & $0.71 \%$ & $0.61 \%$ & $0.47 \%$ & $0.35 \%$ & $0.26 \%$ & $0.24 \%$ & $0.22 \%$ & $0.19 \%$ & $0.15 \%$ & $0.12 \%$ & $0.33 \%$ \\
\hline \multirow{5}{*}{ Pakistan } & Base $(000 \mathrm{MT})$ & 295.61 & 324.75 & 314.85 & 299.88 & 291.51 & 294.40 & 348.89 & 390.97 & 405.75 & 404.46 & 337.11 \\
\hline & $2 \%$ appreciation & $-0.14 \%$ & $-0.16 \%$ & $-0.10 \%$ & $-0.09 \%$ & $-0.09 \%$ & $-0.09 \%$ & $-0.08 \%$ & $-0.08 \%$ & $-0.08 \%$ & $-0.08 \%$ & $-0.10 \%$ \\
\hline & $5 \%$ appreciation & $-0.25 \%$ & $-0.33 \%$ & $-0.20 \%$ & $-0.19 \%$ & $-0.18 \%$ & $-0.15 \%$ & $-0.15 \%$ & $-0.15 \%$ & $-0.15 \%$ & $-0.15 \%$ & $-0.19 \%$ \\
\hline & $15 \%$ appreciation & $-0.73 \%$ & $-0.98 \%$ & $-0.64 \%$ & $-0.58 \%$ & $-0.52 \%$ & $-0.49 \%$ & $-0.47 \%$ & $-0.43 \%$ & $-0.43 \%$ & $-0.42 \%$ & $-0.57 \%$ \\
\hline & $5 \%$ depreciation & $0.24 \%$ & $0.28 \%$ & $0.21 \%$ & $0.17 \%$ & $0.16 \%$ & $0.15 \%$ & $0.15 \%$ & $0.13 \%$ & $0.13 \%$ & $0.13 \%$ & $0.18 \%$ \\
\hline \multirow[t]{5}{*}{ India } & Base (000MT) & 172.01 & 178.19 & 182.71 & 186.01 & 222.44 & 250.43 & 271.70 & 287.90 & 310.24 & 327.21 & 238.88 \\
\hline & $2 \%$ appreciation & $-0.04 \%$ & $-0.08 \%$ & $-0.07 \%$ & $-0.07 \%$ & $-0.07 \%$ & $-0.07 \%$ & $-0.07 \%$ & $-0.07 \%$ & $-0.07 \%$ & $-0.07 \%$ & $-0.07 \%$ \\
\hline & $5 \%$ appreciation & $-0.09 \%$ & $-0.16 \%$ & $-0.14 \%$ & $-0.14 \%$ & $-0.14 \%$ & $-0.14 \%$ & $-0.14 \%$ & $-0.14 \%$ & $-0.14 \%$ & $-0.14 \%$ & $-0.14 \%$ \\
\hline & $15 \%$ appreciation & $-0.26 \%$ & $-0.46 \%$ & $-0.44 \%$ & $-0.43 \%$ & $-0.43 \%$ & $-0.42 \%$ & $-0.42 \%$ & $-0.41 \%$ & $-0.41 \%$ & $-0.41 \%$ & $-0.41 \%$ \\
\hline & $5 \%$ depreciation & $0.08 \%$ & $0.14 \%$ & $0.13 \%$ & $0.13 \%$ & $0.11 \%$ & $0.11 \%$ & $0.11 \%$ & $0.11 \%$ & $0.11 \%$ & $0.11 \%$ & $0.11 \%$ \\
\hline \multirow[t]{5}{*}{ South Korea } & Base (000MT) & 248.30 & 234.92 & 224.51 & 212.85 & 196.28 & 185.90 & 175.83 & 163.36 & 153.28 & 144.94 & 194.02 \\
\hline & $2 \%$ appreciation & $-0.47 \%$ & $-0.46 \%$ & $-0.45 \%$ & $-0.43 \%$ & $-0.42 \%$ & $-0.40 \%$ & $-0.39 \%$ & $-0.39 \%$ & $-0.39 \%$ & $-0.36 \%$ & $-0.42 \%$ \\
\hline & $5 \%$ appreciation & $-0.79 \%$ & $-0.71 \%$ & $-0.64 \%$ & $-0.61 \%$ & $-0.61 \%$ & $-0.60 \%$ & $-0.57 \%$ & $-0.57 \%$ & $-0.57 \%$ & $-0.48 \%$ & $-0.62 \%$ \\
\hline & $15 \%$ appreciation & $-1.11 \%$ & $-1.07 \%$ & $-1.04 \%$ & $-1.04 \%$ & $-1.04 \%$ & $-0.97 \%$ & $-0.94 \%$ & $-0.93 \%$ & $-0.93 \%$ & $-0.93 \%$ & $-1.00 \%$ \\
\hline & $5 \%$ depreciation & $0.74 \%$ & $0.69 \%$ & $0.62 \%$ & $0.61 \%$ & $0.60 \%$ & $0.57 \%$ & $0.52 \%$ & $0.53 \%$ & $0.52 \%$ & $0.45 \%$ & $0.59 \%$ \\
\hline \multirow[t]{5}{*}{ Taiwan } & Base (000MT) & 250.57 & 186.75 & 169.25 & 150.74 & 136.60 & 132.18 & 127.10 & 124.66 & 114.25 & 104.50 & 149.66 \\
\hline & $2 \%$ appreciation & $-0.76 \%$ & $-0.75 \%$ & $-0.70 \%$ & $-0.69 \%$ & $-0.60 \%$ & $-0.58 \%$ & $-0.57 \%$ & $-0.57 \%$ & $-0.55 \%$ & $-0.55 \%$ & $-0.63 \%$ \\
\hline & $5 \%$ appreciation & $-1.45 \%$ & $-1.39 \%$ & $-1.37 \%$ & $-1.31 \%$ & $-1.13 \%$ & $-1.12 \%$ & $-1.08 \%$ & $-1.03 \%$ & $-0.98 \%$ & $-0.95 \%$ & $-1.18 \%$ \\
\hline & $15 \%$ appreciation & $-3.71 \%$ & $-3.17 \%$ & $-2.63 \%$ & $-2.92 \%$ & $-2.78 \%$ & $-2.23 \%$ & $-2.20 \%$ & $-2.05 \%$ & $-1.71 \%$ & $-1.62 \%$ & $-2.50 \%$ \\
\hline & $5 \%$ depreciation & $1.34 \%$ & $1.31 \%$ & $1.29 \%$ & $1.22 \%$ & $1.16 \%$ & $1.06 \%$ & $1.01 \%$ & $0.97 \%$ & $0.89 \%$ & $0.88 \%$ & $1.11 \%$ \\
\hline \multirow[t]{5}{*}{ Japan } & Base $(000 \mathrm{MT})$ & 176.02 & 160.77 & 151.26 & 146.94 & 133.02 & 123.81 & 115.09 & 107.95 & 102.80 & 100.41 & 131.81 \\
\hline & $2 \%$ appreciation & $-1.13 \%$ & $-0.99 \%$ & $-0.96 \%$ & $-0.96 \%$ & $-0.88 \%$ & $-0.88 \%$ & $-0.87 \%$ & $-0.84 \%$ & $-0.78 \%$ & $-0.77 \%$ & $-0.91 \%$ \\
\hline & $5 \%$ appreciation & $-2.66 \%$ & $-2.30 \%$ & $-2.26 \%$ & $-2.11 \%$ & $-2.05 \%$ & $-2.02 \%$ & $-2.00 \%$ & $-1.97 \%$ & $-1.96 \%$ & $-1.90 \%$ & $-2.12 \%$ \\
\hline & $15 \%$ appreciation & $-5.99 \%$ & $-5.75 \%$ & $-5.64 \%$ & $-5.56 \%$ & $-5.33 \%$ & $-5.11 \%$ & $-5.10 \%$ & $-4.91 \%$ & $-4.81 \%$ & $-4.51 \%$ & $-5.27 \%$ \\
\hline & $5 \%$ depreciation & $2.61 \%$ & $2.22 \%$ & $2.23 \%$ & $2.10 \%$ & $1.98 \%$ & $1.98 \%$ & $1.98 \%$ & $1.97 \%$ & $1.96 \%$ & $1.90 \%$ & $2.09 \%$ \\
\hline
\end{tabular}




\section{REFERENCES}

Batten, D. S., and M. T. Belongia, "The Recent Decline in Agricultural Exports: Is the Exchange Rate the Culprit?," Federal Reserve Bank of St. Louis Review, 66, 1984, 5-14.

Bolling, C., "Lower Real Boosts Brazil's Agricultural Exports," International Financial Crises and Agriculture, U.S. Department of Agriculture Economic Research Service, WRS-99-3, March 2000.

Bradsher, K., "China Weighs Modest Currency Change," New York Times, June 10, 2005, p. C4, col. 3.

Chambers, R. G., Applied Production Analysis: A Dual Approach. New York: Cambridge University Press, 1988.

Chambers, R. G., and R. E. Just, "A Critique of Exchange Rate Treatment in Agricultural Trade Markets," American Journal of Agricultural Economics, 61, 1979, 249-57.

, "Effects of Exchange Rate Changes on U.S. Agriculture: A Dynamic Analysis," American Journal of Agricultural Economics, 63, 1981, 32-46.

Clements, K. W., and Y. Lan, "World Fibers Demand," Journal of Agricultural and Applied Economics, 33, 2001, 1-23.

Coleman, J., and M. E. Thigpen, “An Econometric Model of the World Cotton and Non-Cellulosic Fibers Markets," World Bank Staff Commodity Working Paper, 1991.

Editorial Board of the Almanac of China's Textile Industry, Almanac of China's Textile Industry: 1979-99. Beijing: Textile Press of China, 2001.

Fiber Economic Bureau, Fiber Organon, selected issues.

FAPRI, FAPRI 2005 U.S. and World Agricultural Outlook, CARD Staff Report 1-05, Iowa State University, 2005.

Goldstein, M., "China's Exchange Rate Regime," testimony before the Subcommittee On Domestic and International Monetary Policy, Trade and Technology Committee on Financial Services, U.S. House of Representatives, Washington, DC, 2003. Available online at www.iie.com/publications/papers/ goldstein 1003.htm.

Hilsenrath, J. E., and M. Kissel, "Currency Decision Marks Small Shift toward Flexibility," Wall Street Journal, July 22, 2005, p. A1, col. 6.

International Monetary Fund, International Financial Statistics, various issues.

Isadore, C., "The Yuan and the Restless," CNNMoney. com, 2005. Available online at http://money.cnn. com/2005/05/05/news/economy/yuan_revaluation.

Kim, M., G. D. Cho, and W. W. Koo, "Does the Exchange Rate Matter to Agricultural Bilateral Trade Between Canada and the U.S.?," Canadian Journal of Agricultural Economics, 52, 2004, 127-45.

Kristinek, J. J., and D. P. Anderson. "Exchange Rates and Agriculture: A Literature Review," AFPC Working Paper, Agricultural and Food Policy Center, Texas A\&M University, February 2002.

Krueger, A. O., M. Schiff, and A. Valdes, "Agricultural Incentives in Developing Countries: Measuring the Effect of Sectoral and Economywide Policies," World Bank Economic Review, 2, 1988, 255-71.

Kujawa, A. "Diplomacy Resolving Trade Disputes with China," Washington File series on U.S.-China economic relations, April 2005. Available online at www.usembassy-china.org.cn/press/release/2005/ 041805dip.html.
Lau, L., "Lawrence Lau Comments on China's Exchange Rate," Shorenstein APARC News, December 2, 2003. Available online at http://aparc.stanford.edu/news/78.

Li, H., "The Policy Simulation Model of Chinese Fiber Markets," master's thesis, Texas Tech University, 2003.

Meyer, S., "A Model of Textile Fiber Supply and Inter-fiber Competition with Emphasis on the United States," Ph.D. diss., University of Missouri, August 2002.

Miller, N. H., "Notes on Microeconomic Theory," September 5, 2003. Available online at http://ksghome. harvard.edu/ $\sim$ nmiller/notes.htm\#download.

National Statistics Bureau of China, China Industrial Economic Statistical Yearbook, various issues.

- Chinese Rural Statistical Yearbook, various issues.

Organisation for Economic Co-operation and Development and Food and Agriculture Organization of the United Nations "OECD-FAO Agricultural Outlook: 20052014," available online at www.oecd.org/document/5/ 0,2340,en_2649_201185_35015941_1_1_1_1,00.html.

Orden, D. "Exchange Rate Effects on Agricultural Trade". Journal of Agricultural and Applied Economics 34, 2002, 303-312.

Pan, S., S. Mohanty, M. Fadiga, and D. Ethridge. "Structural Models of the United States and the Rest-ofthe-world Natural Fiber Market. " CERI Working Paper \# 04-03, Cotton Economics Research Institute, Department of Agricultural and Applied Economics, Texas Tech University, 2004.

People's Bank of China. "Public Announcement of the People's Bank of China on Reforming the RMB Exchange Rate Regime". Available online at http:// www.pbc.gov.cn/english/detail.asp?col=6400\&id $=542$.

Preeg, E. H. "Exchange Rate Manipulation to Gain an Unfair Competitive Advantage: The Case Against Japan and China", in: Bergsten, C.F. and J. Williamson (eds.) Dollar Overvaluation and the World Economy, Institute for International Economics, Washington, 2003, 267-284.

Schuh, G. E., "The Exchange Rate and U.S. Agriculture," American Journal of Agricultural Economics, 56, 1974, 1-13.

, "Future Directions for Food and Agricultural Trade Policy," American Journal of Agricultural Economics, 66, 1984, 242-47.

Schumer, C. E., and L. O. Graham, "Will It Take a Tariff to Free the Yuan?," New York Times, June 8, 2005.

Segal, D., "A Multi-Product Cost Study of the U.S. Life Insurance Industry," Working paper in Rotman School of Management, University of Toronto, 2002. Available online at www.rotman.utoronto.ca/ accounting/papers/a2002-09.pdf.

Shane, M. D., "Exchange Rate Indexes and U.S. Ag Trade," Agricultural Outlook, January-February 2001, Economic Research Service, U.S. Department of Agriculture, pp. 4-5.

Tweeten, L., Agricultural Trade: Principles and Policies. Boulder, CO: Westview Press, 1992.

USCC, "The China Currency Exchange Rate Problem: Facts and Policy Options," May 9, 2005. Available online at www.uscc.gov/researchpapers/2005/05_05_ 09currency_exchange_rate.htm.

USDA, "Agricultural Baseline Projections," 2005. Available online at www.ers.usda.gov/Briefing/Baseline.

Vellianitis-Fidas, A., "The Impact of Devaluation on U.S. Agricultural Exports," Agricultural Economics Research, 28, 1976, 107-16. 